\title{
Actions for the Restoration of the Biodiversity of Forest Ecosystems in Cuba
}

\author{
Eduardo González Izquierdo, Juan A. Blanco, Gretel Geada López, \\ Rogelio Sotolongo Sospedra, Martín González González, \\ Barbarita Mitjans Moreno, Alfredo Jimenez González and \\ José Sánchez Fonseca
}

Additional information is available at the end of the chapter

http://dx.doi.org/10.5772/59333

\section{Introduction}

Human will and interests have used landscapes without limits for different purposes, usually for the economic benefit of a minority [1]. Nowadays, the Earth is threatened daily by the degradation of its ecosystems due to fragmentation. One of the main consequences is biodiversity loss. Despite the economic progress and conservation actions carried out in many countries, the planet is losing genuine tropical forest, which is distributed mainly in the "low and middle income countries". The reasons are diverse: inappropriate use of extractive practices in forestry related to wood and non-wood products, land use change when clearing the forest for agriculture and cattle ranching, tourism development, and others. These reasons have facilitated the introduction of new species that then behave as invasive species [2], which usually produce strong competition with local species, reducing biomass and the forest's productivity.

Ecological restoration of disturbed areas is one of the most important and complex issues that forestry faces, due to the lack of knowledge on the ecological functioning of populations, communities, ecosystems, and natural landscapes. In addition, we must consider other components such as social, political, and economic interests of the local communities [3]. In ecological restoration, we need to keep in mind four elements as priorities: to develop the conservation of biodiversity; to maintain human use; to empower the local communities in the management of the area; and, at the same time, to improve the productivity of an ecosystem. Thus, ecological restoration can be considered the main component for conservation and for sustainable management programmes, particularly in tropical areas [4]. 
Ecosystems can restore themselves if there are no barriers (biotic or abiotic) that hamper the natural process of passive restoration (natural succession). When ecosystems are too degraded they will not overcome such a state over time, and consequently it will be necessary to implement actions to move the ecosystem towards a succession pathway. This is denominated active or assisted restoration [5]. To improve the design of such active restoration programmes, the study of the vegetable communities contributes important data about the phenological and demographical patterns of species, and species suitable for replacement. Such knowledge will allow estimations of how easy it might be to recover and develop the affected ecosystems [6], and how effective the assisted restoration actions might be.

In this chapter we present the results obtained during the restoration of three tropical forests in Cuba: 1) the mesophyll semi-deciduous forest in the western sector of the Biosphere Reserve "Sierra del Rosario" (BRSR); 2) the riverside forest of the Cuyaguateje River in western Cuba; and 3) the exploited native rainforests of the sector Quibiján-Naranjal of the River Toa in eastern Cuba. The BRSR presents a high variety of ecosystems. Several vegetable formations can be distinguished in the reserve [7-8]: evergreen forest, semi-deciduous forest, and pine forests. The largest formation is semi-deciduous forest, with $40-65 \%$ of deciduous trees, shrubs, herbs, scarce epiphytes, and an abundance of climbers. The predominant variant is the mesophyll semi-deciduous forest [9]. The 22 ha of the riverside forest of the Cuyaguateje River belonging to the cooperative "Menelao Mora" is placed in the Pinar del Río province. The forest is classified as a typical riverside forest with an arboreal stratum of 15-20 m of shrubs, herbs, scarce epiphytes, and climbers [10]. The native rainforests of the sector Quibiján-Naranjal of Toa are considered to be true rainforests in Cuba [11], where there are not deciduous elements with an abundance of epiphytes with two main tree strata from 20-25 m and 8-15 m.

\subsection{Problem statement}

The BRSR is classified according to the International Union for the Conservation of the Nature (UICN) as a Protected Area of Managed Resources: which means that this area type is accorded a larger flexibility for management, conservation, and also some productive activities and services, if done in a sustainable way [6]. This forest has been subjected to extensive exploitation since the sixteenth century, contributing to its degradation and the lack of valuable timber trees and other important species [12]. The riverside forest of the Cuyaguateje was selected because the landownership system (Cooperative farm) supports active agriculture activities. It has the highest degradation grade among the Cuban riverside forests. It is also disturbed by recurrent inundation episodes [13]. The native rainforest was chosen due to its previous intensive exploitation, the current anthropogenic pressure imposed by the adjacent communities [14], and its condition as a rainforest from the Sagua-Baracoa region [11].

At all these sites, disturbances can combine and produce many factors modifying the structure, composition, and functioning of populations, communities, and ecosystems [15], thus changing the availability of resources and habitats. The identification, characterization, and understanding of the communities or types of forests are fundamental in order to manage and conserve forest biodiversity [16]. However, although there are some studies to help us identify and define types of forests in the Neotropic, the information is still limited and more research 
is needed in this area [17], especially in the Caribbean tropical forests. Therefore, conservation and restoration programmes need to include diagnosis in their analysis, for the evaluation of the structure of populations, communities, and ecosystems, and their correlation with present and past disturbances. In this research, we introduce such studies for three different Caribbean forest types.

\section{Material and methods}

\subsection{Application area}

The Biosphere Reserve "Sierra del Rosario" (BRSR) occupies an area of 25,000 ha at 600 metres above sea level (m.a.s.l) in the Artemisa province (western Cuba) from $22^{\circ} 45^{\prime}-23^{\circ} 00^{\prime} \mathrm{N}$ to $82^{\circ} 50$ ' $-83^{\circ} 10^{\prime}$ W. It is part of the National System of Protected Area in Cuba [8]. In the BRSR, the semi-deciduous forest has special importance due to its large area. It constitutes the natural vegetation of Cuba, as high as approximately 600 m.a.s.l. Trees reach a height of 20 to $30 \mathrm{~m}$, the canopy is constituted by two arboreal layers and a shrubby understory, with leaves of approximately 13 to $26 \mathrm{~cm}$ of longitude, mostly compound. The herbaceous layer is usually missing. The highest trees usually lose their leaves during the driest period, while those of the second arboreal layer usually conserve their leaves for the entire year [10].

The riverside forest of the Cuyaguateje is located in the Guane municipality of Pinar del Rio Province, from $22^{\circ} 11^{\prime}-22^{\circ} 13^{\prime} \mathrm{N}$ to $84^{\circ} 03^{\prime}-84^{\circ} 05^{\prime} \mathrm{W}$, at 10 to $30 \mathrm{~m}$.a.s.l. The native rainforests of the sector Quibiján-Naranjal belong to the mountain formation of Nipe-Sagua-Baracoa, in Toa 's river basin in the Guantánamo province (Figure 1). The research site is in the riverside forests of the Cuyaguateje, in the river's middle reaches. This forest's limits to the west are marked by the urban perimeter of Guane, to the north by plantations of the Forest Enterprise Macurije, to the south by the Cooperative of Credits and Strengthened Services "Secundino Serrano", and to the east by the end of the Sierra Cerro of Guane.

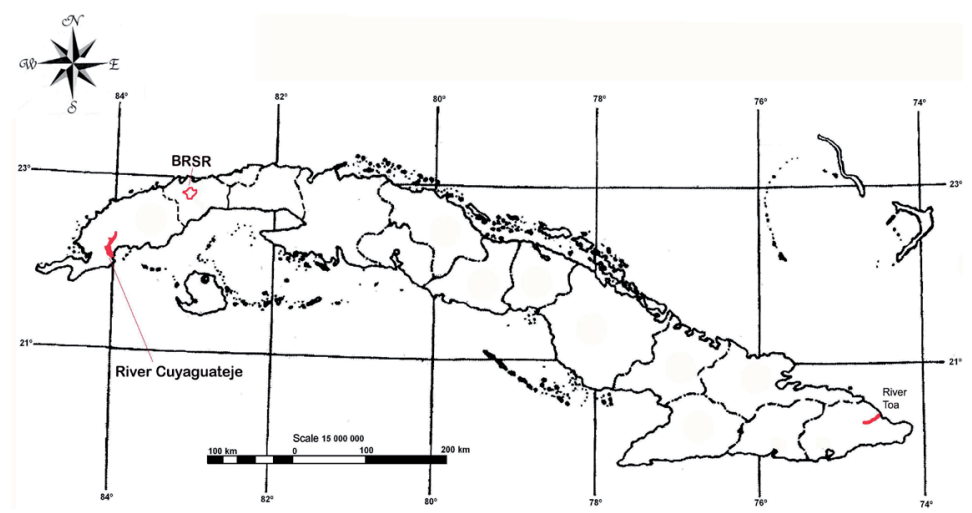

Figure 1. Geographic location of the study cases. BRSR: Biosphere Reserve "Sierra del Rosario". 


\subsection{Field sampling}

First, the study areas were selected as representative units of the described forest type. Later on, sampling plots were chosen where floristic inventories were carried out. Environmental and dasometric variables were also measured. A group of variables related to human interference and its impact on the structure and quality of the forests was assessed, along with the environmental variables (soil, elevation, and distances from different human activities). Finally, a proposal of an action plan for the conservation and restoration of these forests was designed.

A random stratified design was used for field sampling, setting down 0.1 hectares plots $(50 \mathrm{~m}$ x $20 \mathrm{~m}$ ) following the "Methodology of Quick Inventory" [18-19]. In each plot the diameter and height of all the examples of arboreal species (Height $>2 \mathrm{~m}$ and over $5 \mathrm{~cm}$ of $\mathrm{D}_{1.3}$, diameter at breast height) were identified and measured. Environmental variables considered were: nutrient content of soil (ppm) of $\mathrm{Na}, \mathrm{Mg}, \mathrm{K}$, and $\mathrm{Ca}$; $\mathrm{pH}$; content of organic matter in soil (MO); and distance from the centre of the plot to the areas of human activity (cultivated lands, housings, and tourist facilities). Sampling data were validated using the curved area species method.

Diversity indexes were calculated using the floristic data from the inventory. Beta diversity $(\beta)$ was estimated using hierarchical cluster analysis, using Sorensen distance (Bray-Curtis). This distance was estimated as the floristic similarity among the identified groups with the previous analysis calculated with Jaccard's index for qualitative data and the Morisita-Horn index for quantitative data. To identify the indicator species of each one of the identified groups through the cluster analysis, the Dufrene and Legendre method was used [20]. Diversity alpha $(\alpha)$ was calculated with the reciprocal of Simpson index (C inv.) [21], and an unbiased estimator of diversity was calculated using the jack-knife technique.

The horizontal structure was described with the relative values of abundance, dominance, and frequency of each species. In addition, the tree diametric class distributions were described for each plot. The ecological importance index value (IVIE), was calculated for each species as the sum of the parameters in the horizontal structure [22]. To describe the relationships among the variables, a principal components analysis (PCA) was performed, while to determine the association among environmental variables with the distribution and abundance of species for plots a canonical correspondence analysis (CCA) was done.

Key or vulnerable species for high-priority consideration in restoration programmes were identified based on their abundance, dominance, commercial wood potential, and dasometric variables. The design of the restoration proposal was based on the approaches of [5] who suggest 13 steps for restoration strategies.

\section{Results}

\subsection{Study of case No. 1: Mesophyll semi-deciduous forest of the Biosphere Reserve "Sierra del Rosario" (BRSR)}

We identified 36 families, 75 genera, and 91 species, with a total of 7,799 individuals registered from 30 sampled plots. The endemism rate was $11.24 \%$, a similar value reported for the 
complete BRSR (from 11 to 34\% [7]). The cluster analysis showed the presence of three groups among the plots, according to the flora composition. This result was tested by the MRPP test, which revealed differences among groups $(\mathrm{p}<0.001)$ and supported the classification into three clusters. The analysis of species indicator [18] in each group is shown in Table 1.

\begin{tabular}{|c|c|c|c|c|c|c|c|}
\hline Indicator species & Groups & IVI & $p$ & Indicator species & Groups & IVI & $p$ \\
\hline Bursera simaruba & \multirow{5}{*}{1} & 72.3 & 0.01 & Oxandra lanceolata & \multirow{13}{*}{3} & 90,9 & 0.01 \\
\hline Guettarda sp. & & 68.4 & 0.01 & Laurocerasus occidentalis & & 74,2 & 0.01 \\
\hline Matayba apetala & & 68.0 & 0.01 & Zanthoxylum martinicense & & 65,7 & 0.01 \\
\hline Andira inermis & & 61.7 & 0.02 & Pithecellobium arboreum & & 60,5 & 0.02 \\
\hline Nectandra coriacea & & 59.6 & 0.02 & Caesalpinia bahamensis & & 60,0 & 0.01 \\
\hline Trophis racemosa & & 72.4 & 0.01 & Swietenia mahagoni & & 60,0 & 0.01 \\
\hline Casearia mollis & & 67.9 & 0.01 & Tabebuia shaferi & & 57,0 & 0.01 \\
\hline Cupania americana & & 62.9 & 0.01 & Cedrela odorata & & 56,9 & 0.04 \\
\hline Guazuma ulmifolia & 2 & 52.8 & 0.02 & Didymopanax morototoni & & 50,8 & 0.02 \\
\hline Roystonea regia & & 52.6 & 0.04 & Rauwolfia nitida & & 49,7 & 0.01 \\
\hline Trichilia hirta & & 50.1 & 0.04 & Erythrina poeppigiana & & 48,7 & 0.03 \\
\hline \multirow[t]{2}{*}{ Spondias mombin } & & 47.1 & 0.02 & Poeppigia procera & & 45,0 & 0.02 \\
\hline & \multicolumn{4}{|r|}{ Eugenia maleolens } & & 40,0 & 0.01 \\
\hline
\end{tabular}

Table 1. Indicator species for the three groups, ordered by their IVI $(\mathrm{p}<0.05)$, obtained in the floristic inventory carried out in the western sector of BRSR.

According to these results, species related to the secondary forest that could be associated with a disturbance like timber extraction predominate in groups 1 and 2. Group 3 contained species from preserved sites, which correspond with plots in the Natural Reserve El Mulo. The results of the CCA analysis were globally significant. The first three axes offered a good solution to the ordination of the sampling units and of the species, because due to the present total variability in the data of abundance of the species (inertia $=2.55$ ) it was possible to explain $23.7 \%$ by means of the group of this axes. The analyses reveal that the effect of the soil is not significant in the distribution and presence of species and therefore in the classification of the samples. The variable distance to human establishments has a bigger effect, mainly related with the plots of group 1 that are the furthest away and therefore less affected by the anthropic action. Group 3 is separated by the composition of species in the parcels or plots of the El Mulo located in more conserved area corresponding to the area nucleus of the reserve (Figure 2). 


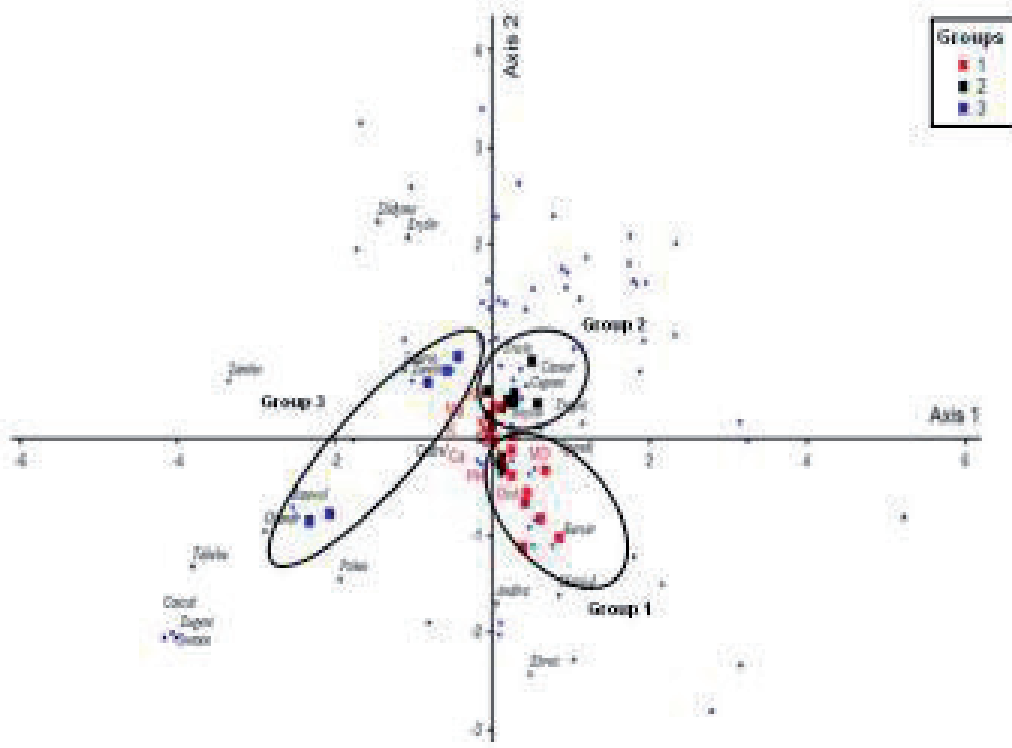

Figure 2. Projection of environmental variables, sampling units, and species in the plane defined by the axes CCA1 and CCA2. The continuous explanatory variables are shown as lines, the categorical explanatory variable is indicated by the colour of sampling unit, and the species with the codes given to their names.

The diversity of species and the equitability (alpha diversity) did not show significant differences ( $p>0.05$ ) among localities. Therefore, in general, both variables can be considered to have high values. Numerically the areas of El Mulo and Mogote have a higher value that corroborates the characteristic vegetation for the complex of vegetation of Mogote [9]. In the case of El Mulo, the category of "Natural Reserve" favours its conservation and therefore displayed a higher diversity value (Table 2 ).

\begin{tabular}{lcc}
\hline \multicolumn{1}{c}{ Sites } & Simpson (1/C) VPi & Equitativity (E) VP \\
\hline San Ramón & $17.51 \pm 3.09$ & $.8510 \pm 0.05$ \\
\hline Mogote & $18.52 \pm 8.54$ & $.8521 \pm 0.03$ \\
\hline Brazo Fuerte & $16.73 \pm 2.03$ & $.8581 \pm 0.03$ \\
\hline Los Hondones & $16.33 \pm 1.05$ & $.8518 \pm 0.04$ \\
\hline El Mulo & $20.31 \pm 2.13$ & $.8231 \pm 0.06$ \\
\hline Average & $17.88 \pm 3.50$ & $.8500 \pm 0.04$ \\
\hline
\end{tabular}

Table 2. Average of dear diversity by means of the method of "Calculation Jump" (jack-knifing) for mesophyll semideciduous forest in the western sector of the BRSR. 


\begin{tabular}{|c|c|c|c|c|c|}
\hline No & Species & AR & FR & $\mathrm{DmR}$ & IVIE \\
\hline 1 & Roystonea regia & 2,9 & 93,3 & 6,23 & 102,48 \\
\hline 2 & Trophis racemosa & 7,1 & 90,0 & 0,75 & 97,87 \\
\hline 3 & Matayba apetala & 9,5 & 83,3 & 1,93 & 94,75 \\
\hline 4 & Pseudolmedia spuria & 5,4 & 86,7 & 0,50 & 92,53 \\
\hline 5 & Bursera simaruba & 4,1 & 83,3 & 2,53 & 89,94 \\
\hline 6 & Guarea guidonia & 8,3 & 80,0 & 1,57 & 89,88 \\
\hline 7 & Ficus aurea & 0,7 & 66,7 & 21,22 & 88,55 \\
\hline 8 & Calophyllum antillanun & 4,8 & 80,0 & 1,03 & 85,83 \\
\hline 9 & Andira inermis & 2,2 & 80,0 & 1,92 & 84,11 \\
\hline 10 & Cecropia schreberiana & 1,5 & 80,0 & 2,18 & 83,70 \\
\hline 11 & Syzygium jambos & 6,7 & 70,0 & 1,08 & 77,79 \\
\hline 12 & Cupania americana & 2,4 & 70,0 & 0,29 & 72,70 \\
\hline 13 & Matayba domingensis & 4,6 & 63,3 & 1,72 & 69,67 \\
\hline 14 & Cinnamomun elongatum & 2,0 & 66,7 & 0,37 & 69,08 \\
\hline 15 & Guazuma ulmifolia & 2,1 & 63,3 & 1,88 & 67,29 \\
\hline
\end{tabular}

Table 3. First 15 arboreal species located by their Value of Ecological Importance in mesophyll semi-deciduous forest in the western sector of the BRSR.

\subsubsection{Horizontal structure}

The tree species with a higher ecological importance were those with a higher frequency (over $60 \%$ ), so abundance and dominance are more important to the IVIE. Roystonea regia appears in the first position as the typical species in this forest. Other species, such as Trophis racemosa and Matayba apetala, are important because of their abundances, and Ficus aurea for its dominance (Table 3).

In the El Mogote, the species Guarea guidonia, Roystonea regia, Bursera simaruba, and Matayba apetala were present in the lowest and the middle parts, showing how their distributions are central to the altitudinal distribution of this formation [10]. The species Cecropia schreberiana was located among the most important by its relative dominance. It has very few individuals with small diameters that inhabit the most exposed places to light. This distribution favours the establishment of early secondary communities. Such communities evolve to establish a homeostasis in an approximately ten-year period. Then they stabilize the canopy in places that have suffered natural or anthropogenic disturbances. This behaviour is typical of pioneer species that will be later substituted in the successional process. Syzygium jambos is among the most abundant species, and it shows a high migration capacity, confirming their invasive condition. The abundance of these species demonstrates an increase in the populations of this group of plants and they indicate an altered ecological integrity. 
Within the species with intermediate abundance, Calycophyllum candidissimun, Dendropanax arboreus, and Samanea saman hold special interest for future conservation strategies. The species Chione cubensis, Lagetta wrightiana, and Terminalia chicharronia (classified as endemic in "Sierra del Rosario") have a low abundance. However, those species were reported as being very abundant in this formation [10]. In our inventories, their presence only in the areas of San Ramón and Brazo Fuerte gave them the classification of being rare species. Among the most dominant species, the high presence of Ficus aurea is the outcome of selective felling being carried out in these forests, due to the scarce commercial value of Erythrina poeppigiana. Roystonea regia, Mangifera indica, Laurocerasus occidentalis, Swietenia mahagoni, and Zanthoxylum martinicense all reached $59 \%$ dominance.

The biggest values of basal area $\left(\mathrm{m}^{2} / \mathrm{ha}\right)$ for the mesophyll semi-deciduous forest were found for the western sector of the reserve, in the areas of El Mulo and Brazo Fuerte. The species Ficus aurea with $23.7 \mathrm{~m}^{2} /$ ha and Erythrina poeppigiana with $18.9 \mathrm{~m}^{2} /$ ha showed the biggest values in this parameter.

\subsubsection{Vertical structure}

These forests presented a high height, with two strata whose emergent trees are Calophyllum antillanun, Andira inermis, Roystonea regia, Pseudolmedia spuria, and Matayba apetala. All these species can reach up to $35 \mathrm{~m}$ in the hollows of San Ramón de Aguas Claras, Los Hondones, Brazo Fuerte, and in the low altitudes of the western part of "El Mogote de Soroa". The canopy was composed of individuals with heights from 20 to $30 \mathrm{~m}$, with slight differences between the areas of hillsides and the summits. In the nature reserve El Mulo, the forest has two arboreal floors. The top stratum (more than $25 \mathrm{~m}$ in height) contained emergent Ficus aurea, Eritrina poeppigiana, Cecropia schreberiana, Didymopanax morototoni, Trichospermun mexicanum, and Roystonea regia, among other species. The trees in this layer reach up to 30-35 $\mathrm{m}$ in height. The intermediate stratum of mesophyll semi-deciduous forest in the studied areas is occupied by trees between 15 to $10 \mathrm{~m}$ tall. The lower stratum was integrated by evergreen species that reached heights of 6 to $12 \mathrm{~m}$. The lower stratum is composed of juvenile individuals of the most abundant and frequent species, such as: Trophis racemosa, Guarea guidonia, Bursera simaruba, Pseudolmedia spuria, Syzygium jambos, Calophyllum antillanun, and Dendropanax cuneifolius. Trees in the lower stratum are usually younger individuals. Regeneration is fundamentally of species typical of secondary forests, except in El Mulo where Matayba apetala had regenerated. The similar abundance of sharing species among strata of the forest (Table 4) was determined by the Morisita-Horn index giving analogous values ( $\geq 80 \%)$.

\begin{tabular}{lcccc}
\hline & $\begin{array}{c}\mathrm{D}_{1,3}<5 \mathrm{~cm} \text { height } \\
<1,5 \mathrm{~m}\end{array}$ & $\begin{array}{c}\mathrm{D}_{1,3}<5 \mathrm{~cm} \text { height } \\
\mathbf{1 1 , 5} \mathbf{m}\end{array}$ & $\begin{array}{c}\mathrm{D}_{1,3} \geq \mathbf{5} \leq \mathbf{1 0} \mathrm{cm} \text { height } \\
\mathbf{1 1 , 5} \mathrm{m}\end{array}$ & $\begin{array}{c}\mathrm{D}_{1,3} \geq \mathbf{1 0} \mathrm{cm} \text { height } " / \\
>\mathbf{1 , 5} \mathrm{m}\end{array}$ \\
\hline $\mathrm{D}_{1,3}<5 \mathrm{~cm}$ height $<1,5 \mathrm{~m}$ & 0,92 & 0,87 & 0,80 \\
\hline $\mathrm{D}_{1,3}<5 \mathrm{~cm}$ height $\geq 1,5 \mathrm{~m}$ & & 0,90 & 0,85 \\
\hline $\mathrm{D}_{1,3} \geq 5 \leq 10 \mathrm{~cm}$ height $\geq 1,5 \mathrm{~m}$ & & & 0,80 \\
\hline $\mathrm{D}_{1,3} \geq 10 \mathrm{~cm}$ height $">1,5 \mathrm{~m}$ & & & \\
\hline
\end{tabular}

Table 4. Morisita-Horn index of the components of the vertical structure of mesophyll semi-deciduous forest 


\subsubsection{Disturbances and relationship with the forest status}

Ecological disturbances were classified according to their intensity in a scale from 1 to 4 , where 1 = without disturbance; 2 = light; 3 = moderate; and 4 = high disturbance. Selective felling, alterations for the construction of roads, clearings, and the felling of trees due to winds, firewood extraction, and for other non-timber forest products were evaluated according to this scale. It was proven that the anthropogenic alterations prevailed: the most intense were related with selective felling, one of the factors that alters the dynamics of the regeneration more than others, changing the structure and composition of the forest.

Results of the principal components analysis were displayed on a correlation matrix between variables describing disturbance and variables describing species structure (Table 5). This table reveals that the first three orthogonal components explain $67 \%$ of the present variability. The variables that contributed more to the segregation of the components were: maximum number of individuals, selective felling, total number of individuals, and dominance. The first component reveals theinverse relationship between speciesnumber and basal area versus environmental variables such as the distance of the sampling places from the populated areas and forest clearings. The second and third components confirmed the direct relationship between the quantity of individuals and variables such as the intensity of selective felling, extraction of nontimber forest products, and road construction. The high density of individuals in the perturbed places is related to canopy opening and high regeneration of heliophill(sun tolerant) species, which usually have small diameters and therefore low values of basal area.

\begin{tabular}{|c|c|c|c|c|}
\hline \multirow[b]{2}{*}{ Variable } & \multirow{2}{*}{ Communality } & \multicolumn{3}{|c|}{ Component } \\
\hline & & 1 & 2 & 3 \\
\hline Specie richness & ,725 &,- 773 & ,306 &,- 183 \\
\hline Clearings and fall of trees & ,617 & ,766 & &,- 157 \\
\hline Diversity (1/D) & ,776 & 624 & & 620 \\
\hline Distance & 609 & 607 & &,- 489 \\
\hline Basal area & 414 &,- 601 &,- 231 & \\
\hline Selective felling & 860 & & ,919 & \\
\hline Firewood extraction and non-timber forest product (NTFP) & 638 & ,236 & ,753 & 121 \\
\hline Total of individual numbers & ,777 &,- 295 & 635 &, 535 \\
\hline Individual numbers of the most abundant species & 877 & & ,338 & 869 \\
\hline Total Roads impact & 408 &,- 158 &,- 355 &, 507 \\
\hline Auto value & & 2,486 & 2,2111 & 2,003 \\
\hline$\%$ of variance & & 24,862 & 22,105 & 20,031 \\
\hline$\Sigma \sigma^{2}$ & & 24,862 & 46,967 & 66,998 \\
\hline
\end{tabular}

Table 5. Main components analysis based on the correlation matrix between the disturbance variables and structural variables. 
The relationship among sites, species, and some environmental variables indicates that Swietenia mahagoni, Oxandra lanceolata, Tabebuia shaferi, and Caesalpinia bahamensis, among others, reached the biggest values of abundance in environments with low disturbance. This fact indicates that these taxa are characteristic of places only slightly altered, like in the parcels of El Mulo.

Figure 3 shows the results of classifying the sampling units (plots) according to their disturbance grade.

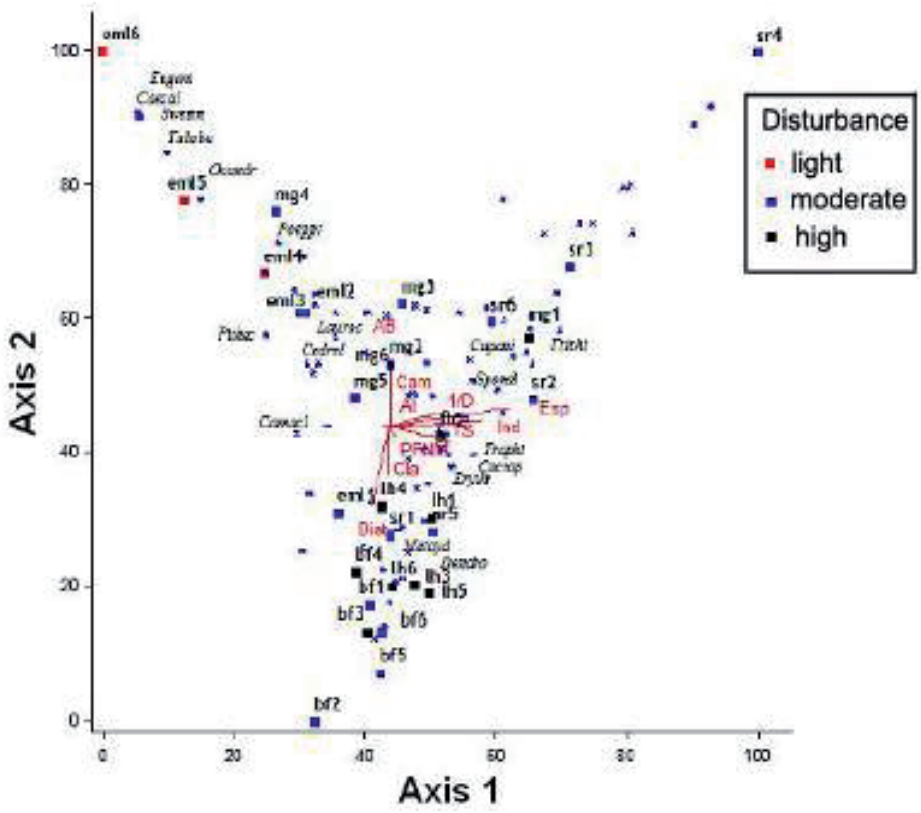

Figure 3. Projection of sampling units (squares) and species (asterisks) in the plane defined by the first two axes of the ACP. The continuous explanatory variables are shown as lines and the categorical explanatory variable is shown according to the colour of the symbol of the sampling unit. Sampling places: (sr1-sr6) - plots of San Ramón; mg1-mg6 plots of El Mogote; bf1-bf6 - plots of Brazo Fuerte; lh1 a lh6 - plots of Los Hondones; eml1-eml6 - plots of El Mulo. Variables: Dist - distances to populational establishments and other human activities; AB - Basal area; Cam roads; AL - height of sea level; 1/D - diversity; TS - selective felling; Esp - specie richness; Ind - individuals' maximum number; PFNM - Non-timber forest products; Cla - Forest spacements. Species codes: (Eugeni - Eugenia maleolens); (Caesal - Caesalpinia bahamensis); (Tabebu - Tabebuia shaferi); (Pithec - Pithecellobium arboreum); (Oxandr Oxandra lanceolata); (Poepi - Poeppigia procera); (Cedrel - Cedrela odorata); (Comocl - Comocladia dentata); (Lauroc Laurocerasus occidentalis); (Sweten - Swietenia mahagoni); (Matayd - Matayba domingensis); (Cupani - Cupania americana); (Trophi - Trophis racemosa); (Cecrop - Cecropia shreberiana); (Erythr - Erythroxyllum havanense); (Spondi - Spondias mombin); (Trichi - Trichilia havanensis); (Dendro - Dendropanax arboreus).

Secondary species characteristic of mesophyll semi-deciduous forest that generally have little commercial value, such as Matayba apetala and Trophis racemosa, were more abundant in places with moderate to high disturbance levels. These sites coincide with the plots in Brazo Fuerte, 
Los Hondones, and San Ramón, characterized by the presence of the biggest diversity alpha, and the largest presence of species and abundance. According to these results the hypothesis of intermediate disturbance is corroborated [23]. Such a hypothesis states that the opening of forest gaps favours a much higher level of diversity (at local and regional scales) that would be presented if they lacked those disturbances.

On the other hand, the species Swietenia mahagoni and Caesalpinia bahamensis have a perfect correlation with sites with the lowest disturbance level, according to the test of Dufrene and Legendre [20]. Such correlation was demonstrated in the field, as these species were located very close to the plots of El Mulo. The opposite result was found for Cupania americana and Cecropia schreberiana, which were mostly present in sites with a high degree of disturbance. They were observed very near the most perturbed places of Brazo Fuerte, Los Hondones, El Mogote, and San Ramón.

In accordance with the results, indicator species were not present under conditions of moderate disturbance. Such species are fundamentally pioneer species of very wide distribution that surpass different ecological conditions, related with the alteration of environment. Indicator species with a significance level $(\mathrm{p}<0.05)$ are shown in Table 6. Swietenia mahagoni and Caesalpinia bahamensis could be considered as perfect indicators of the lowest disturbance level. On the other hand, Cupania americana and Cecropia schreberiana were the best indicators of a high degree of disturbance.

\begin{tabular}{|c|c|c|c|c|c|c|c|}
\hline Indicator species & Disturbance & IVI & $\mathrm{p}^{*}$ & Indicator species & Disturbance & IVI & $\mathrm{p}^{*}$ \\
\hline Caesalpinia bahamensis & \multirow{10}{*}{ Light } & 100,0 & 0,001 & Cecropia schreberiana & \multirow{9}{*}{ High } & 71,0 & 0,001 \\
\hline Swietenia mahagoni & & 100,0 & 0,001 & Cupania americana & & 69,9 & 0,001 \\
\hline Tabebuia shaferi & & 97,5 & 0,002 & Trichilia havanensis & & 68,4 & 0,021 \\
\hline Oxandra lanceolata & & 91,2 & 0,002 & Trophis racemosa & & 63,6 & 0,003 \\
\hline Poeppigia procera & & 81,3 & 0,002 & Dendropanax cuneifolius & & 62,4 & 0,019 \\
\hline Pithecellobium arboreum & & 80,9 & 0,003 & Matayba apetala & & 53,4 & 0,032 \\
\hline Comocladia dentata & & 68,6 & 0,013 & Roystonea regia & & 53,3 & 0,047 \\
\hline Eugenia maleolens & & 66,7 & 0,013 & Erythroxyllum havanense & & 50,0 & 0,042 \\
\hline Laurocerasus occidentalis & & 62,6 & 0,019 & Spondias mombin & & 47,1 & 0,032 \\
\hline Cedrela odorata & & 61,3 & 0.020 & & & & \\
\hline
\end{tabular}

Factor level: 2 - Light; 4 - High.

Table 6. Lists of the main indicator species ordered for IVI $(\mathrm{p}<0.05)$ according to the disturbance level.

\subsubsection{Diameter structure of forest species in the reserve}

The number of woody species of local and commercial interest was reduced, and their diameter distributions presented few individuals in superior categories (Table 7). This can be the result 
of selective commercial logging, described as one of the main disturbances in the region. These results corroborate those outlined in [24], for "Sierra del Rosario". These authors concluded that in that region, only a few individuals end up having diameters bigger than $20 \mathrm{~cm}$, due to topography and shallow soils. Although the diversity of trees is high, the abundance of forestry species' regeneration with commercial value is low in the mesophyll semi-deciduous forest of the reserve.

\begin{tabular}{|c|c|c|c|c|c|c|c|c|c|c|c|c|}
\hline \multirow{2}{*}{ Species } & \multicolumn{12}{|c|}{ Number of trees for diameter class $d_{(1,3)}(\mathrm{cm})$} \\
\hline & Total & $2,5-9$ & $10-19$ & $20-29$ & $30-39$ & $40-49$ & $50-59$ & $60-69$ & $70-79$ & $80-89$ & $90-99$ & $\geq 100$ \\
\hline Matayba apetala & 502 & 333 & 128 & 40 & 1 & & & & & & & \\
\hline Guarea guidonia & 471 & 346 & 67 & 35 & 10 & 6 & 2 & 1 & 2 & 1 & 1 & \\
\hline Bursera simaruba & 420 & 188 & 172 & 44 & 9 & 3 & & 2 & & 2 & & \\
\hline Calophyllum antillanum & 347 & 254 & 48 & 27 & 10 & 2 & 3 & 1 & 1 & & 1 & \\
\hline Trichospermun mexicanum & 206 & 57 & 89 & 42 & 14 & 3 & 1 & & & & & \\
\hline Andira inermis & 189 & 111 & 51 & 22 & 5 & & & & & & & \\
\hline Oxandra lanceolata & 149 & 99 & 30 & 12 & 6 & 2 & & & & & & \\
\hline Laurocerasus occidentalis & 141 & 91 & 32 & 12 & 4 & 1 & 1 & & & & & \\
\hline Mangifera indica & 130 & 56 & 3 & & 7 & 4 & 7 & 31 & 8 & 2 & 7 & 5 \\
\hline Zanthoxylum martinicense & 122 & 52 & 20 & 21 & 21 & 3 & 2 & 1 & & & 2 & \\
\hline Talipariti elatum & 116 & 62 & 19 & 12 & 7 & 11 & 2 & 3 & & & & \\
\hline
\end{tabular}

Table 7. Structure of the diameter class of arboreal species with more than 100 individuals in the sampling places in the western sector of the BRSR.

It seems that in the reserve there is a considerable quantity of species tolerant to disturbances, such as Talipariti elatum, Bursera simaruba, Calophyllum antillanun, Laurocerasus occidentalis, and Guarea guidonia. They regulate the diametric structure that favours their presence in the forest. This phenomenon could indicate their possible use in reforestation programmes. On the other hand, species of high commercial value like Swietenia mahagoni and Cedrela odorata are only represented by 28 and 45 individuals, respectively. The stand diametric structure reveals very few individuals in the regeneration category, and also a very minor presence in other diametric classes. This situation puts the future existence of these species at risk.

\subsubsection{Indicator species}

The regular form in the diametric distribution observed in Matayba apetala, Guarea guidonia, Bursera simaruba, and Calophyllum antillanun, with an abundance of juvenile individuals in the inferior categories, suggests tolerance to the competition caused by disturbances in the forest. Therefore, some of these species could be incorporated into a monitoring programme for these ecosystems. Due to their quick growth, they could also be considered for inclusion in a restoration programme in the region. In this context, among the arboreal species suggested as key species are: Guarea guidonia, Matayba apetala, Pseudolmedia spuria, Calophyllum antillanun, Laurocerasus occidentalis, Mangifera indica, Cecropia schreberiana, and Bursera simaruba. These 
species possess additional attributes that allow them to provide stability to the ecosystem before the disturbances [21]. The approaches that endorse this selection are related in the following.

Large trees of Mangifera indica found in San Ramón de Aguas Claras, El Mogote, Brazo Fuerte, and Los Hondones support a high epiphytic diversity, with flowers like orchids, bromeliads, and others. In addition, such epiphytes are also an important element for wildlife food sources (mainly birds and small mammals), whose populations could be at risk in this reserve. Many fruits are also collected by the residents of the local communities for their own consumption. In "Sierra del Rosario", the presence of Cecropia schreberiana allows the establishment of early secondary communities. Such communities develop a homeostasis in around a 10-year cycle, stabilizing the canopy in places that have suffered natural or anthropogenic disturbances. Other species like Trophis racemosa and Syzygium jambos could be suggested as indicator species of highly disturbed forests in this region. Trophis racemosa is located mainly in the medium to high altitudes, while Syzygium jambos is distributed in the medium to low areas near rivers or streams.

\subsubsection{Vulnerable species}

In an alarming way, individuals of some commercially important species such as Lagetta wrightiana and Terminalia chicharronia, which were previously plentiful in these forests (as local residents remember), were present only in the inventories of San Ramón de Aguas Claras and Brazo Fuerte, respectively. For the last species, individuals were not observed in natural regeneration inside the sampled plots. This result supports its consideration of species under threat, according to the species Red List of Cuba [9].

\subsubsection{Restoration proposal}

The purpose of the proposal is to suggest a group of actions to guide restoration and conservation of forests in the western sector of the BRSR and adjacent areas. In the elaboration of this proposal, the approaches by [5] have been considered. These authors suggest 13 steps or main elements to consider in the elaboration of the plan. These are:

1. To define the ecosystem or reference community;

2. To evaluate the current state of the ecosystem or community;

3. To define the scales or levels of organization of the ecosystem;

4. To establish the scales and disturbance hierarchies;

5. To achieve the local human community's participation;

6. To evaluate the potential of regeneration of the ecosystem;

7. To establish the restoration barriers at different scales;

8. To select the appropriate species for restoration;

9. To spread and to manage the selected species; 
10. To select the intervention sites;

11. To design strategies to overcome the barriers to the restoration;

12. Monitoring the restoration processes;

13. To consolidate the restoration process.

According to the previous steps, the actions for the restoration have been based on the following aspects: 1) it has been kept in mind the previous main scientific research studies carried out in the area that today occupies the Biosphere Reserve of "Sierra del Rosario". Among these, the book Ecology of Rainforests of Sierra del Rosario [7] constitutes a summary of the main research carried out in this ecosystem. Other important studies considered aspects of the geology in relation with the presence of hydrocarbons in the eastern part of the reserve [26], agrobiodiversity that the farmers manage in homemade orchards and properties in protected areas [27], and restoration of arboreal diversity of rainforests in the reserve [6]. Also, analysis of research needs in the protected area [30], and the floristic characterization of mesophyll semi-deciduous forest in the western sector of the BRSR, as well as a group of indicator environmental variables of disturbances.

When proposing the restoration plan, we also kept in mind the results of floristic inventories carried out in the Biosphere Reserve of "Sierra del Rosario", as well as the impacts of the traditional extraction of products of forest and other land uses. We also tried to incorporate the perceptions and identification of the environmental services of forest by the local residents of the reserve, according to the approaches of [28]. Opinions of the technical staff of the Ecological Station (the state entity responsible for the protection of the BRSR), and recommendations of experts on the basic approaches for the conservation and the sustainable forest administration $[27,6]$ were also taken into account. In addition, guidelines by International Organization of Tropical Wood for restoration, ordination, and rehabilitation of secondary and degraded tropical forests [29], as well as recommendations on the Methodology for the Elaboration of Management Plans for Protected Areas of Cuba [30], were incorporated. Finally, the Management Plan of the Biosphere Reserve of "Sierra del Rosario" for the period 20112015 and the operative Plan of the Reserve were consulted [8].

After this review, it was determined that the main barriers to the restoration are:

- Natural barriers: dominance of species with little commercial value, invasion of exotic species, irregularities in the diameter classes in distribution of species of high commercial value, and gaps in the forest as a result of the wind and the falling of trees.

- Social barriers: selective logging, firewood extraction, non-timber forest products harvesting, and road construction.

Recommended actions for forest restoration:

- Adoption of modern silviculture techniques, such as favouring passive reforestation (natural regeneration), enrichment of the natural forest, reforestation with native species, and implementation of agroforestry or silvopastoral systems. 
- To reach higher percentages of natural regeneration in places affected by windthrow, selective logging, road construction, or agricultural cultivation, the following species are recommended for restoration: Matayba apetala, Guarea guidonia, Bursera simaruba, and Calophyllum antillanun. The species with commercial use are: Andira inermis, Swietenia mahagoni, Laurocerasus occidentalis, Terminalia chicharronia, and Gerascanthus gerascanthoides.

- A high-priority is given to the recovery of native forest species whose populations are in critical state, such as Lagetta wrightiana and Terminalia chicharronia. Similarly, reintroduction of trees with beautiful wood that have been extinguished locally, such as Cedrela odorata and Swietenia mahagoni, is also a high-priority.

\subsection{Study of case No. 2: Riparian forest of the River Cuyaguateje}

\subsubsection{Biodiversity}

For alpha diversity, floristic inventories in both borders of the studied area were done every $323 \mathrm{~m}$ and natural regeneration was estimated. The specie richness was 38 species, including 21 families and 36 genera. Table 8 shows the 860 individuals of the species (> $2 \mathrm{~m}$ of height). Similar results were reported in previous studies [31-32] and also referred to by local farmers since the 1970s. The most representative species found were Bambusa vulgaris, Guazuma ulmifolia, Samanea saman, Sapindus saponaria, Lonchocarpus domingensis, Spondias mombin, Roystonea regia, Trichilia hirta, and Bursera simaruba. Natural regeneration in passive restoration allows abundant recruitment of autochthonous species such as G. ulmifolia, S. saponaria, L. domingensis, T. citrifolia, S. mahagoni, T. hirta, T. elatum, and S. mombin. These species can create more suitable habitats for other typical species, reducing the impacts of human activities [33] and increasing ecological resilience.

\begin{tabular}{lccccc}
\hline \multicolumn{1}{c}{ Species } & Individuals & Dr & Species & Individuals & Dr \\
\hline $\begin{array}{l}\text { Bambusa vulgaris Schrader ex } \\
\text { Wendland }\end{array}$ & 191 & 22,2 & Psidium guajava L. & 15 & 1,74 \\
\hline Guazuma ulmifolia Lam. & 87 & 10,1 & Cephalanthus occidentalis L. & 14 & 1,63 \\
\hline Samanea saman (Jacq.) & 79 & 9,19 & Roystonea regia HBK O. F. Cook. & 13 & 1,51 \\
\hline $\begin{array}{l}\text { Sapindus saponaria L. } \\
\text { Lonchocarpus domingensis (Pers). DC. }\end{array}$ & 42 & 4,88 & Swietenia macrophyla King. & 12 & 1,40 \\
\hline $\begin{array}{l}\text { Tabernaemontana citrifolia L. } \\
\text { Swietenia mahagoni } \text { L }\end{array}$ & 42 & 4,88 & Gliricidia sepium Jacq. Urb. & 10 & 1,16 \\
\hline \begin{tabular}{l} 
Trichilia hirta L. \\
\hline
\end{tabular} & 37 & 4,30 & Tabebuia angustata Britt. & 7 & 0,81 \\
\hline
\end{tabular}




\begin{tabular}{|c|c|c|c|c|c|}
\hline Species & Individuals & Dr & Species & Individuals & Dr \\
\hline Gmelina arborea Roxb & 34 & 3,95 & Terminalia catappa $\mathrm{L}$ & 6 & 0,70 \\
\hline Talipariti elatum Frixell (Sw.) & 32 & 3,72 & $\begin{array}{l}\text { Andira inermis (W. Wright) Kunth } \\
\text { ex DC. }\end{array}$ & 4 & 0,47 \\
\hline Spondias mombin $\mathrm{L}$ & 26 & 3,02 & Casearia hirsuta Sw & 3 & 0,35 \\
\hline Guarea guidonia L. Sleumer & 21 & 2,44 & Melicoccus bijugatus Jacq & 3 & 0,35 \\
\hline Cordia collococca $\mathrm{L}$ & 17 & 1,98 & Annona reticulata $\mathrm{L}$ & 2 & 0,23 \\
\hline Cedrela odorata $\mathrm{L}$ & 16 & 1,86 & Comocladia dentata Jacq & 2 & 0,23 \\
\hline Gerascanthus gerascanthoides L. & 16 & 1,86 & Cupania americana $\mathrm{L}$. & 2 & 0,23 \\
\hline $\begin{array}{l}\text { Dichrostachys cinerea }(\mathrm{L}) \text { Wigth et } \\
\text { Arm }\end{array}$ & 16 & 1,86 & Cocos nucifera $\mathrm{L}$ & 1 & 0,12 \\
\hline \multirow[t]{2}{*}{ Acacia mangium Willd. } & 15 & 1,74 & Khaya senegalensis Desr (A. Juss.) & 1 & 0,12 \\
\hline & & & Total & 860 & 100 \\
\hline
\end{tabular}

Table 8. Arboreal and shrub species identified in the area in the riversides of the River Cuyaguateje ( $>2 \mathrm{~m}$ height).

During the first year (2000) the area could be recognized by the presence of scarce trees of eight species along the riverside. Figure 4 illustrates how specie richness increased during the rehabilitation process, simultaneously with the reduction of the human cultivation practices, extensive shepherding, and sand extraction from the riverbed.

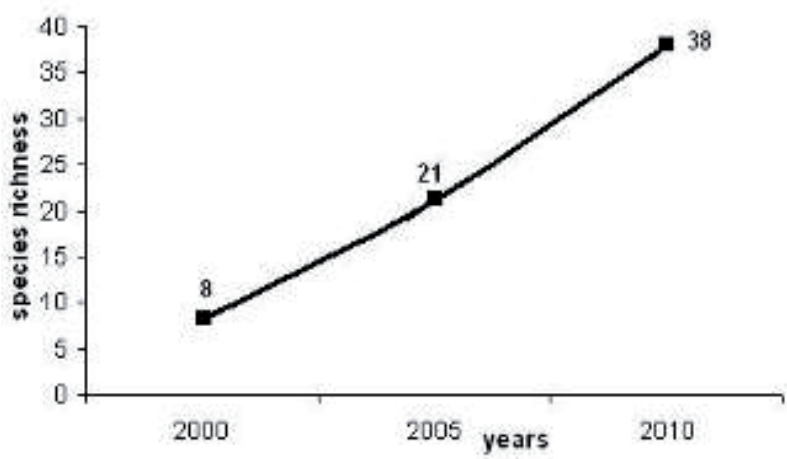

Figure 4. Specie richness trends during the period (2000-2010) according to [13]. 
Table 9 represents biodiversity expressed by Simpson's index and its reciprocal in each research plot. The highest values of diversity corresponded to plots 3,5 , and 8 in the border 1 , and plots 18,24, 25, and 30 in the border 2 . These plots correspond to locations where local farmers had implemented forest rehabilitation measures by themselves. Generally speaking, biodiversity values per plot varied from 1.29 to 12.61 in border 1 , and from 0.62 to 14.25 in border 2. Such a trend clearly shows the differences among sites with and without human activity in both borders, since the topography and soils are similar in the whole studied area.

\begin{tabular}{|c|c|c|c|c|c|}
\hline \multicolumn{3}{|c|}{ Border 1} & \multicolumn{3}{|c|}{ Border 2} \\
\hline Plots & Dominance (D) & Diversity (I/D) & Plots & Dominance (D) & Diversity (I/D) \\
\hline 1 & 0.22 & 4.50 & 18 & $0.08^{*}$ & $12.20^{*}$ \\
\hline 2 & 0.21 & 4.75 & 19 & 0.14 & 7.35 \\
\hline 3 & $0.12^{*}$ & $8.61^{*}$ & 20 & 0.09 & 10.60 \\
\hline 4 & 0.22 & 4.61 & 21 & 0.27 & 3.72 \\
\hline 5 & $0.11^{*}$ & $9.23^{*}$ & 22 & 0.22 & 4.62 \\
\hline 6 & 0.40 & 2.80 & 23 & 0.24 & 4.11 \\
\hline 7 & 0.20 & 6.51 & 24 & $0.07^{*}$ & $14.25^{*}$ \\
\hline 8 & $0.08^{*}$ & $12.61^{*}$ & 25 & $0.08^{*}$ & $12.05^{*}$ \\
\hline 9 & 0.50 & 2.20 & 26 & 0.61 & 0.62 \\
\hline 10 & 0.27 & 3.67 & 27 & 0.19 & 5.60 \\
\hline 11 & 0.39 & 2.60 & 28 & 0.12 & 8.56 \\
\hline 12 & 0.57 & 1.74 & 29 & 0.16 & 6.18 \\
\hline 13 & 0.51 & 1.97 & 30 & $0.19^{*}$ & $11.27^{*}$ \\
\hline 14 & 0.78 & 1.29 & 31 & 0.15 & 6.30 \\
\hline 15 & 0.40 & 2.50 & 32 & 0.09 & 10.50 \\
\hline 16 & 0.39 & 3.05 & 33 & 0.16 & 8.11 \\
\hline 17 & 0.35 & 2.30 & 34 & 0.15 & 6.66 \\
\hline
\end{tabular}

Table 9. Dominance index and their reciprocal one, of the individuals with $\mathrm{d} 1.3 \geq 2.5 \mathrm{~cm}$ for plots in each border

The plots with the highest diversity values $(8,18,24,25$, and 30) could be used as examples of the expected restoration targets for riparian forests in terms of floristic composition. However, they show some signs of past anthropogenic intervention. Ecologically speaking, these plots form a complex mosaic as a result of the processes that favour ecological resilience, thus increasing biodiversity values.

As for beta-diversity and Jaccard's index of similarity, they are very important for assessing the degree of similarity among communities and the degree of exclusion between two species 
within the same community, especially when the species become dominant [34-35]. Jaccard's index indicates similarity between rehabilitated borders $(0.78)$ that have 29 species in common (Table 10$)$. Indeed, the high value in flora similarity between borders $(0.78)$ is probably due to the response to similar climatic factors (temperature, humidity, and precipitation), soil type, and latitudinal position, while the differences could be related to structural elements of common species.

\begin{tabular}{|c|c|c|c|}
\hline Number & Species & Number & Species \\
\hline 1 & Acacia mangium Willd & 16 & Melicoccus bijugatus Jacq. \\
\hline 2 & Andira inermis (W. Wright) Kunth ex DC. & 17 & Psidium guajava $\mathrm{L}$. \\
\hline 3 & Anonna reticulata $\mathrm{L}$ & 18 & Roystonea regia $\mathrm{HBK}$ O. F. Cook. \\
\hline 4 & Bambusa vulgaris Schrader ex Wendland & 19 & Samanea saman Jacq. \\
\hline 5 & Bursera simaruba (L) Sargent. & 20 & Sapindus saponaria $\mathrm{L}$. \\
\hline 6 & Casearia hirsuta Sw & 21 & Simaruba glauca D.C. \\
\hline 7 & Cordia collococca $\mathrm{L}$ & 22 & Spondias mombin $\mathrm{L}$ \\
\hline 8 & Cupania americana $\mathrm{L}$. & 23 & Swietenia mahagoni $\mathrm{L}$ \\
\hline 9 & Dichrostachys cinerea (L) Wigth et Arm. & 24 & Swietenia macrophyla King. \\
\hline 10 & Gerascanthus gerascanthoides L. & 25 & Tabernaemontana citrifolia $\mathrm{L}$. \\
\hline 11 & Gmelina arborea Roxb. & 26 & Talipariti elatum Frixell (Sw) \\
\hline 12 & Guarea guidonia L. Sleumer & 27 & Terminalia catappa $\mathrm{L}$ \\
\hline 13 & Guazuma ulmifolia Lam. & 28 & Trichilia havanensis Jacq. \\
\hline 14 & Lonchocarpus domingensis (Pers). DC. & 29 & Trichilia hirta L. \\
\hline 15 & Mangifera indica L. & & \\
\hline
\end{tabular}

Table 10. Species in common in both borders that been rehabilitated.

In addition, another element that should be considered in support of this analogy is the occurrence of floods that favour seed dispersion and natural regeneration of pioneer species, while reducing anthropogenic pressure and the presence of typical vegetation such as $G$. ulmifolia, L. domingensis, T. citrifolia, T. hirta, S. mombin, and S. saponaria. Among both communities (rehabilitated and control sites) an index of similarity of 0.28 with 14 common species was reported (Table 11). The small similarity between the control and rehabilitated sites could be caused by the short time of the rehabilitation process, the differences include the environmental conditions, and the human cultivation activities that enhance the presence of species, many of which exhibit invasive behaviour.

If agriculture, extensive shepherding, and sand extraction activities were controlled, while local actors managed the natural regeneration by increasing species numbers (even with exotic species), better ecological conditions will develop in the long term for the transition towards 
a rehabilitated site, improving the ecosystem's functionality. In addition, such favourable conditions (fertility, humidity, and deposition of seeds) for natural regeneration and the plantation of species like T. elatum and S. mahagoni would improve the ecosystem's productivity. In this sense, in some cases ecosystems degraded anthropogenically can be restored when the external stresses are reduced, with the reintroduction of native species, the removal of the exotic species, and the beginning of the passive restoration processes [36].

\begin{tabular}{|c|c|c|}
\hline Species (natural area) & Species (rehabilitated area) & Common in both areas \\
\hline Alibertia edulis (L. C. Richt.) & Acacia mangium Willd & Bursera simaruba L. Sargent. \\
\hline Calycophyllum candidissimun (Vahl) DC. & Andira inermis (W. Wright) Kunth & Casearia hirsuta Sw. \\
\hline Cinnamomun elongatum (Nees) Kostermans & Anonna reticulata $\mathrm{L}$. & Comocladia dentata Jacq \\
\hline Cochlospermun vitifolium (Willd.) & $\begin{array}{l}\text { Bambusa vulgaris Schrader ex } \\
\text { Wendland }\end{array}$ & Cupania americana $\mathrm{L}$. \\
\hline Chrysophyllum cainito L. & $\begin{array}{l}\text { Calophyllum antillanum (Britt.) } \\
\text { Standl. }\end{array}$ & Guarea guidonia L. Sleumer \\
\hline Erythroxylum havanense Jacq. & Cedrela odorata $\mathrm{L}$. & Guazuma ulmifolia Lam. \\
\hline Gossypiospermum praecox (Gris.) P. Wilson & Cephalanthus occidentalis L. & Lonchocarpus domingensis (Pers). DC. \\
\hline Luehea speciosa Willd. & Cocos nucifera $\mathrm{L}$. & Roystonea regia HBK O. F. Cook. \\
\hline Matayba apetala Macf. RDKL. & Cordia collococca $\mathrm{L}$. & Sapindus saponaria $\mathrm{L}$. \\
\hline Oxandra lanceolata Sw. Baill. & $\begin{array}{l}\text { Dichrostachys cinerea (L.) Wigth et } \\
\text { Arm. }\end{array}$ & Spondias mombin $\mathrm{L}$ \\
\hline Protium cubense (Rose) & Gerascanthus gerascanthoides L. & Syzygium jambos L. Alston in Trimen \\
\hline \multirow[t]{13}{*}{ Zanthoxylum elephantiasis Macfd. } & Gliricidia sepium Jacq. Urb. & Tabernaemontana citrifolia L. \\
\hline & Gmelina arborea Roxb. & Trichilia hirta $\mathrm{L}$. \\
\hline & Khaya senegalensis Juss & Trichilia havanensis Jacq. \\
\hline & Mangifera indica L. & \\
\hline & Melicoccus bijugatus Jacq. & \\
\hline & Psidium guajava L. & \\
\hline & Samanea saman (Jacq.) & \\
\hline & Simaruba glauca D.C. & \\
\hline & Swietenia mahagoni $\mathrm{L}$. & \\
\hline & Swietenia macrophyla King. & \\
\hline & Tabebuia angustata Britt. & \\
\hline & Talipariti elatum Frixell (Sw.) & \\
\hline & Terminalia catappa L. & \\
\hline
\end{tabular}

Table 11. Species identified in the study area (rehabilitated and control) 
Figures 5 and 6 show a diagram of range/abundance of the species in the borders. At both sites, the highest abundance value corresponds to $S$. jambos, which in Cuba is an invasive species linked to human activities. This species is a fruit-bearing shrub introduced in Cuba. It later colonized some mountainous areas along riversides and constitutes a serious obstacle for reforestation.
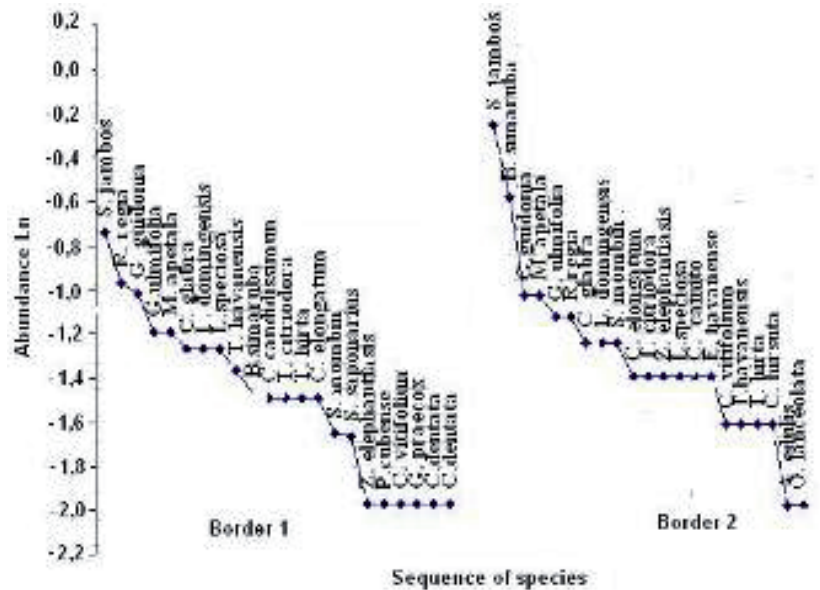

Figure 5. Diagram of the range/abundance of identified species in riversides (1 and 2) of the Cuyaguateje's riversides according to [13].

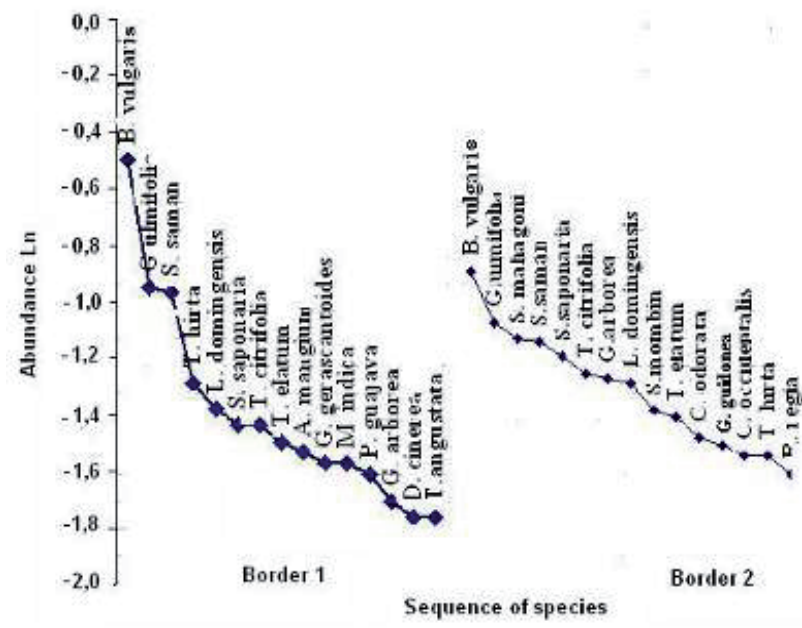

Figure 6. Diagram of the range/abundance for the 15 more representative species of the area that is rehabilitated in borders (1 and 2) of the Cuyaguateje's riversides according to [13] 


\subsubsection{Forest structure}

Table 12 shows the results of horizontal structural parameters of rehabilitated areas under local communities' participation (dominance (D), abundance (A), and frequency (F)), and the ecological importance value index (IVIE) of the species in each border. The species with low IVIE are those typical of the riparian forest, such as: B. simaruba, A. inermis, C. dentata, $C$. americana, S. mahagoni, and $R$. regia. According to their relative abundance, the species most sensitive to environmental or anthropogenic disturbances were identified: A. inermis, $C$. dentata, S. macrophyla, S. mahagoni, A. reticulata, and $R$. regia. This parameter can be used as an indicator of the degrading process [34,37]. Similarly, in border 2 the species with low IVIE had more commercial importance, such as G. arborea, S. saman, G. ulmifolia, L. domingensis, S. mahagoni, T. elatum, S. saponaria, and R. regia (Table 12). In the case of G. arborea, the value of the IVIE was due to its dominance. This species is not recommended for planting along riversides because it is considered as potentially invasive [38]. It is also not recommended for planting in sites prone to floods due its low survival rate under such conditions.

\begin{tabular}{|c|c|c|c|c|c|c|c|c|c|}
\hline \multicolumn{5}{|c|}{ Border 1} & \multicolumn{5}{|c|}{ Border 2} \\
\hline Species & Dr & Fr & Ar & IVIE & Species & Dr & Fr & Ar & IVIE \\
\hline Bambusa vulgaris & 6,93 & 9,01 & 31,70 & 47,63 & Bambusa vulgaris & 11,53 & 5,52 & 13,69 & 30,73 \\
\hline Samanea saman & 20,78 & 11,71 & 10,81 & 43,30 & Gmelina arborea & 19,63 & 4,83 & 5,74 & 30,20 \\
\hline Guazuma ulmifolia & 17,47 & 9,01 & 11,30 & 37,78 & Samanea saman & 13,39 & 8,28 & 7,73 & 29,39 \\
\hline Lonchocarpus domingensis & 3,99 & 7,21 & 4,18 & 15,37 & Guazuma ulmifolia & 9,99 & 6,21 & 9,05 & 25,25 \\
\hline Sapindus saponaria & 2,87 & 7,21 & 3,69 & 13,76 & Lonchocarpus domingensis & 5,00 & 7,59 & 5,52 & 18,10 \\
\hline Acacia mangium & 8,75 & 1,80 & 2,95 & 13,50 & Swietenia mahagoni & 4,14 & 5,52 & 7,95 & 17,61 \\
\hline Trichilia hirta & 3,42 & 4,50 & 5,16 & 13,08 & Talipariti elatum & 8,25 & 4,83 & 4,19 & 17,27 \\
\hline Spondias mombin & 7,89 & 3,60 & 1,47 & 12,97 & Sapindus saponaria & 3,49 & 6,21 & 6,84 & 16,54 \\
\hline Gmelina arborea & 5,65 & 3,60 & 1,97 & 11,22 & Roystonea regia & 8,82 & 4,14 & 2,65 & 15,61 \\
\hline Mangifera indica & 2,70 & 5,41 & 2,70 & 10,81 & Spondias Bombin & 3,63 & 6,21 & 4,42 & 14,25 \\
\hline Tabernaemontana citrifolia & 1,18 & 5,41 & 3,69 & 10,27 & Tabernaemontana citrifolia & 0,52 & 6,21 & 5,96 & 12,69 \\
\hline Talipariti elatum Frixell & 3,97 & 2,70 & 3,19 & 9,87 & Trichilia hirta & 0,29 & 4,83 & 3,09 & 8,21 \\
\hline Gerascanthus gerascanthoides & 2,64 & 4,50 & 2,70 & 9,85 & Cedrela odorata & 1,83 & 2,07 & 3,53 & 7,44 \\
\hline Psidium guajava & 1,47 & 3,60 & 2,46 & 7,53 & Cordia collococca & 0,81 & 3,45 & 2,43 & 6,69 \\
\hline Cordia collococca & 3,15 & 2,70 & 1,47 & 7,33 & Swietenia macrophyla & 1,81 & 2,76 & 1,99 & 6,56 \\
\hline Tabebuia angustata & 1,36 & 2,70 & 1,72 & 5,78 & Guarea guidonia & 0,30 & 2,76 & 3,31 & 6,37 \\
\hline Guarea guidonia & 0,97 & 2,70 & 1,47 & 5,15 & Cephalanthus occidentalis & 0,18 & 2,07 & 3,09 & 5,33 \\
\hline Bursera simaruba & 1,21 & 1,80 & 1,23 & 4,24 & Dichrostachys cinerea & 0,90 & 2,07 & 1,99 & 4,95 \\
\hline Terminalia catappa & 0,89 & 1,80 & 1,23 & 3,92 & Gliricidia sepium & 1,25 & 1,38 & 1,55 & 4,17 \\
\hline
\end{tabular}




\begin{tabular}{|c|c|c|c|c|c|c|c|c|c|}
\hline \multicolumn{5}{|c|}{ Border 1} & \multicolumn{5}{|c|}{ Border 2} \\
\hline Species & Dr & Fr & Ar & IVIE & Species & Dr & Fr & Ar & IVIE \\
\hline Andira inermis & 0,58 & 1,80 & 0,49 & 2,87 & Acacia mangium & 0,95 & 2,07 & 0,66 & 3,68 \\
\hline Dichrostachys cinerea & 0,08 & 0,90 & 1,72 & 2,70 & Psidium guajava & 0,33 & 2,07 & 1,10 & 3,50 \\
\hline Comocladia dentata & 1,15 & 0,90 & 0,49 & 2,54 & Andira inermis & 1,43 & 1,38 & 0,44 & 3,25 \\
\hline Casearia hirsuta & 0,03 & 0,90 & 0,74 & 1,67 & Gerascanthus gerascanthoides & 0,52 & 1,38 & 1,10 & 3.00 \\
\hline Cupania americana & 0,15 & 0,90 & 0,49 & 1,54 & Melicoccus bijugatus & 0,03 & 2,07 & 0,66 & 2,76 \\
\hline Swietenia macrophyla & 0,31 & 0,90 & 0,25 & 1,46 & Cocos nucifera & 0,37 & 0,69 & 0,22 & 1,28 \\
\hline Swietenia mahagoni & 0,22 & 0,90 & 0,25 & 1,36 & Khaya senegalensis & 0,37 & 0,69 & 0,22 & 1,28 \\
\hline Annona reticulata & 0,14 & 0,90 & 0,25 & 1,29 & Bursera simaruba & 0,21 & 0,69 & 0,22 & 1,12 \\
\hline Roystonea regia. & 0,05 & 0,90 & 0,25 & 1,20 & Annona reticulata & 0,03 & 0,69 & 0,22 & 0,94 \\
\hline \multirow[t]{3}{*}{ Totals } & 100 & 100 & 100 & 300 & Mangifera indica & 0,01 & 0,69 & 0,22 & 0,92 \\
\hline & & & & & Terminalia catappa & 0,01 & 0,69 & 0,22 & 0,92 \\
\hline & & & & & Totals & 100 & 100 & 100 & 300 \\
\hline
\end{tabular}

Table 12. Phytosociological Parameters of the riparian forest of the River Cuyaguateje, border (1 and 2). Dr = Relative Dominance; $\mathrm{Fr}=$ Relative Frequency; $\mathrm{Ar}=$ Relative Abundance; IVIE = Ecological Importance Value Index

Fruit tree species were present with very low values in frequency, dominance, and abundance. Only P. guajava, M. indica, A. reticulata, and M. bijugatus were observed. Local farmers did not accept $M$. bijugatus because this species is a potentially invasive species [38]. The scarcity in fruits could also be related to the low germination and development rates of Pouteria campechiana (canistel) and Calocarpum sapota (Red Mammee) and the low presence of this species in natural areas. Incorporating fruit trees to reforestation plans could be used as an incentive for local farmers to protect riversides.

Natural regeneration reflects ecosystem fitness. Our results show a good condition with 3,952 in border 1 and 4,564 seedlings in border 2 . Nonetheless, it is important to compare the species in the upper canopy stratum with those that are regenerating because their relative frequencies are directly associated to successional processes [36]. Our results indicate that favourable conditions exist for the regeneration and the recruitment of arboreal and shrub species that can increase or diminish in the measure that restrictive factors changes. Logically, it is also related to the approval of local farmers of rehabilitation processes [13].

At both borders, regenerated individuals in the herbaceous stratum were found for G. ulmifolia, S. saman, L. domingensis, S. saponaria, G. guidonia, R. regia, T. citrifolia, S. mombin, S. saponaria, T. elatum, C. collococca, L. domingensis, and B. simaruba, which are typical species of this forest type. The relative natural regeneration (RNRi) index, which combines abundance and frequency, showed the higher values for T. citrifolia, S. saman, G. ulmifolia, S. mombin, L. domingensis, and S. saponaria. Of the nine species that were used at the beginning of the reforestation [39] only four were presented in this stratum: G. arborea, T. elatum, M. indica, and P. guajava. However, 
very good germination rates of G. arborea were observed, a typical feature of invasive species. Its successful establishment will depend on flooding events and silvicultural management.

Table 13 shows the values of the Modified Ecological Importance Value Index (IVIEA) for both borders. The IVIEA is the most important indicator in evaluating forest dynamics [40]. It integrates horizontal and vertical structures in the mature mass, as in the natural regeneration. S. saman, B. vulgaris, G. ulmifolia, G. arborea, and S. saponaria were the most important species. Likewise, there are correspondences among plants that are identified in the arboreal stratum and natural regeneration processes in both borders. The appearance of new species in the inferior stratum, not identified in the mature state, indicates the existence of seeds and environmental factors that favour the ultimate rehabilitation of the forest. Source [29] considers that the readiness of different regeneration mechanisms is a crucial factor in the speed and course of secondary succession. Nevertheless, reproduction by seeds is the main mechanism of regeneration of the widely dispersed pioneer species, especially after repeated cultivationfallow cycles over long periods.

\begin{tabular}{|c|c|c|c|c|c|c|c|c|c|c|c|c|}
\hline & Borc & $\operatorname{der} 1$ & & & & & Borc & ler 2 & & & & \\
\hline Species & Ar & Fr & Dr & IVIr & RNRi & IVIE & Ar & Fr & Dr & IVIr & RNRi & $\begin{array}{c}\text { IVIE } \\
\mathrm{A}\end{array}$ \\
\hline Samanea saman & 20,8 & 11,7 & 10,8 & 43,3 & 8,7 & 52,0 Gmelina arborea & 19,6 & 4,8 & 5,7 & 30,2 & 13,1 & 43,3 \\
\hline Bambusa vulgaris & 6,9 & 9,0 & 31,7 & 47,6 & 2,3 & 49,9 Samanea saman & 13,4 & 8,3 & 7,7 & 29,4 & 5,5 & 34,9 \\
\hline Guazuma ulmifolia & 17,5 & 9,0 & 11,3 & 37,8 & 6,1 & 43,9 Bambusa vulgaris & 11,5 & 5,5 & 13,7 & 30,7 & & 30,7 \\
\hline $\begin{array}{l}\text { Tabernaemontana } \\
\text { citrifolia }\end{array}$ & 1,2 & 5,4 & 3,7 & 10,3 & 11,4 & 21,7 Guazuma ulmifolia & 10,0 & 6,2 & 9,1 & 25,2 & 3,6 & 28,9 \\
\hline Sapindus saponaria & 2,9 & 7,2 & 3,7 & 13,8 & 6,5 & 20,2 Sapindus saponaria & 3,5 & 6,2 & 6,8 & 16,5 & 9,5 & 26,0 \\
\hline $\begin{array}{l}\text { Lonchocarpus } \\
\text { domingensis }\end{array}$ & 4,0 & 7,2 & 4,2 & 15,4 & 4,2 & 19,6 Talipariti elatum & 8,2 & 4,8 & 4,2 & 17,3 & 5,1 & 22,4 \\
\hline Trichilia hirta & 3,4 & 4,5 & 5,2 & 13,1 & 6,5 & $19,5 \begin{array}{l}\text { Lonchocarpus } \\
\text { domingensis }\end{array}$ & 5,0 & 7,6 & 5,5 & 18,1 & 3,3 & 21,4 \\
\hline Spondias mombin & 7,9 & 3,6 & 1,5 & 13,0 & 6,1 & 19,0 Roystonea regia & 8,8 & 4,1 & 2,6 & 15,6 & 4,7 & 20,4 \\
\hline Gmelina arborea & 5,6 & 3,6 & 2,0 & 11,2 & 5,7 & $16,9 \begin{array}{l}\text { Tabernaemontana } \\
\text { citrifolia }\end{array}$ & 0,5 & 6,2 & 6,0 & 12,7 & 7,3 & 20,0 \\
\hline Acacia mangium & 8,7 & 1,8 & 2,9 & 13,5 & & 13,5 Swietenia mahagoni & 4,1 & 5,5 & 7,9 & 17,6 & & 17,6 \\
\hline Talipariti elatum & 4,0 & 2,7 & 3,2 & 9,9 & 3,4 & 13,3 Spondias Bombin & 3,6 & 6,2 & 4,4 & 14,3 & 2,9 & 17,2 \\
\hline $\begin{array}{l}\text { Gerascanthus } \\
\text { gerascanthoides }\end{array}$ & 2,6 & 4,5 & 2,7 & 9,9 & 3,0 & 12,9 Trichilia hirta & 0,3 & 4,8 & 3,1 & 8,2 & 6,9 & 15,1 \\
\hline Mangifera indica & 2,7 & 5,4 & 2,7 & 10,8 & 0,8 & 11,6 Guarea guidonia & 0,3 & 2,8 & 3,3 & 6,4 & 7,3 & 13,7 \\
\hline
\end{tabular}


Border 1

\begin{tabular}{|c|c|c|c|c|c|c|c|c|c|c|c|c|c|}
\hline & Bor & der 1 & & & & & & Bor & der 2 & & & & \\
\hline Species & Ar & Fr & Dr & IVIr & RNRi & $\begin{array}{c}\text { IVIE } \\
\text { A }\end{array}$ & Species & Ar & Fr & Dr & IVIr & RNRi & $\begin{array}{c}\text { IVIE } \\
\mathrm{A}\end{array}$ \\
\hline Psidium guajava & 1,5 & 3,6 & 2,5 & 7,5 & 3,0 & 10,6 & Cordia collococca & 0,8 & 3,4 & 2,4 & 6,7 & 1,8 & 8,5 \\
\hline Cordia collococca & 3,2 & 2,7 & 1,5 & 7,3 & 2,7 & 10,0 & $\begin{array}{l}\text { Cephalanthus } \\
\text { occidentalis }\end{array}$ & 0,2 & 2,1 & 3,1 & 5,3 & 2,9 & 8,3 \\
\hline Cupania americana & 0,1 & 0,9 & 0,5 & 1,5 & 8,4 & 9,9 & Cedrela odorata & 1,8 & 2,1 & 3,5 & 7,4 & & 7,4 \\
\hline Tabebuia angustata & 1,4 & 2,7 & 1,7 & 5,8 & 3,0 & 8,8 & Swietenia macrophyla & 1,8 & 2,8 & 2,0 & 6,6 & & 6,6 \\
\hline Guarea guidonia & 1,0 & 2,7 & 1,5 & 5,2 & 2,3 & 7,4 & Dichrostachys cinerea & 0,9 & 2,1 & 2,0 & 5,0 & 1,1 & 6,0 \\
\hline Terminalia catappa & 0,9 & 1,8 & 1,2 & 3,9 & 2,7 & 6,6 & Cupania americana & & & & & 5,5 & 5,5 \\
\hline Bursera simaruba & 1,2 & 1,8 & 1,2 & 4,2 & 1,5 & 5,8 & Terminalia catappa & 0,0 & 0,7 & 0,2 & 0,9 & 4,0 & 4,9 \\
\hline Comocladia dentata & 1,1 & 0,9 & 0,5 & 2,5 & 3,0 & 5,6 & Gliricidia sepium & 1,2 & 1,4 & 1,5 & 4,2 & 0,7 & 4,9 \\
\hline Andira inermis & 0,6 & 1,8 & 0,5 & 2,9 & 1,1 & 4,0 & Psidium guajava & 0,3 & 2,1 & 1,1 & 3,5 & 1,1 & 4,6 \\
\hline Roystonea regia & 0,1 & 0,9 & 0,2 & 1,2 & 2,3 & 3,5 & $\begin{array}{l}\text { Gerascanthus } \\
\text { gerascanthoides }\end{array}$ & 0,5 & 1,4 & 1,1 & 3,0 & 1,5 & 4,5 \\
\hline Dichrostachys cinerea & 0,1 & 0,9 & 1,7 & 2,7 & 0,8 & 3,5 & Andira inermis & 1,4 & 1,4 & 0,4 & 3,3 & 1,1 & 4,3 \\
\hline Trichilia havanensis & & & & & 2,3 & 2,3 & Melicoccus bijugatus & 0,0 & 2,1 & 0,7 & 2,8 & 1,1 & 3,9 \\
\hline Melicoccus bijugatus & & & & & 2,3 & 2,3 & Acacia mangium & 0,9 & 2,1 & 0,7 & 3,7 & & 3,7 \\
\hline Casearia hirsuta & 0,0 & 0,9 & 0,7 & 1,7 & & 1,7 & Bursera simaruba & 0,2 & 0,7 & 0,2 & 1,1 & 1,8 & 2,9 \\
\hline Swietenia macrophyla & 0,3 & 0,9 & 0,2 & 1,5 & & 1,5 & Mangifera indica & 0,0 & 0,7 & 0,2 & 0,9 & 1,8 & 2,7 \\
\hline Swietenia mahagoni & 0,2 & 0,9 & 0,2 & 1,4 & & 1,4 & Casearia hirsuta & & & & & 2,2 & 2,2 \\
\hline Anonna reticulata & 0,1 & 0,9 & 0,2 & 1,3 & & 1,3 & Trichilia havanensis & & & & & 1,5 & 1,5 \\
\hline \multirow[t]{7}{*}{ Total } & 100 & 100 & 100 & 300 & 100 & 400 & Cocos nucifera & 0,4 & 0,7 & 0,2 & 1,3 & & 1,3 \\
\hline & & & & & & & Khaya senegalensis & 0,4 & 0,7 & 0,2 & 1,3 & & 1,3 \\
\hline & & & & & & & Simaruba glauca & & & & & 1,1 & 1,1 \\
\hline & & & & & & & Anonna reticulata & 0,0 & 0,7 & 0,2 & 0,9 & & 0,9 \\
\hline & & & & & & & Syzygium jambos & & & & & 0,7 & 0,7 \\
\hline & & & & & & & Calophyllum antillanun & & & & & 0,7 & 0,7 \\
\hline & & & & & & & Total & 100 & 100 & 100 & 300 & 100 & 400 \\
\hline
\end{tabular}

Table 13. Phytosociological parameters of riparian forest of the River Cuyaguateje area that becomes rehabilitated border (1 and 2), including (IVIEA). Ar = Relative Abundance; $\mathrm{Fr}=$ Relative Frequency; $\mathrm{Dr}=$ Relative Dominance IVIE $=$ Relative Importance Value Index; RNRi = Relative Natural Regeneration, IVIEA = Enlarged Ecological Importance Value Index

Border 2 
Figure 7 represents the horizontal structure of this forest, expressed by their distribution in three diameter classes. It shows irregularity in their distribution, characteristic of forests that recover from disturbances mostly by natural regeneration. The biggest frequency values were registered in the diameter classes from 2 to $10 \mathrm{~cm}$ and the smallest frequencies were found for diameter classes of $20 \mathrm{~cm}$ and bigger. This is the typical histogram in an inverted "J". Such a result agrees with [41], who states that forests age irregularly, and that species have the biggest frequency of individuals in small diameter classes. In general, it seems that the ecosystem is formed by heterogeneous populations with irregular diameter classes. This has been previously reported for most forests with a complex structure [42-43]. This result also indicates that previous reforestation efforts by state institutions using forest plantations were not suitable, as they did not mimic natural diameter distributions but provided the opportunity for natural regeneration to begin.

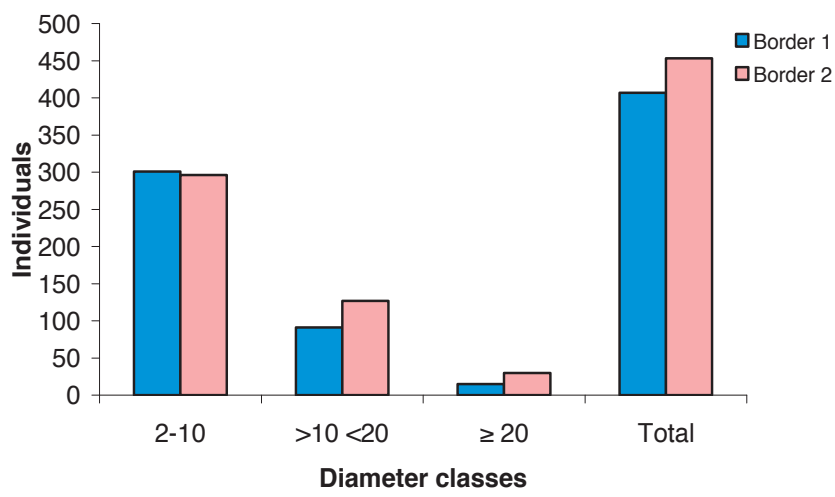

Figure 7. Distribution of all individuals in three diameter classes (Borders 1 and 2 of the area that is rehabilitated) in the Cuyaguateje's riversides.

As for the vertical structure, we found different strata (Figure 8). Although tree ages did not exceed 10 years, disparity in height was observed. Lower in the canopy were those species that present less resilience under disturbances (natural and artificial), because environmental conditions favour pioneer species. Tree height in border 2 is higher, mainly due to the presence of G. arborea and B. vulgaris. In general, frequency distribution in the form of an inverted "J" is certain, fundamentally for low seedling survival rates in plantations during the first years. The largest quantity of individuals have settled down through the natural regeneration in the last few years, although there is the presence of some individuals in the superior strata (up to 20 $\mathrm{m}$ in height) as a result of the plantations carried out during the early years.

At both borders, the biggest abundance of individuals was found for the smallest height classes ( 2 to $5 \mathrm{~m}$ ), at $56 \%$. As tree height increased, the number of individuals proportionally decreased, reaching less than $8 \%$ in the class for $10 \mathrm{~m}$ or more of height. At the two borders, $69 \%$ 
of the individuals were present in the smallest heights. Only $5 \%$ were found reaching heights above $20 \mathrm{~m}$. In this case, they were individuals of R. regia, S. saman, or S. mombin. These species coincided with those that farmers reported as existing in the riverside before 1970. This fact confirms the date when the water dam "The Cuyaguateje" was built and intensive sand extraction with heavy equipment began along the whole riverside [44].

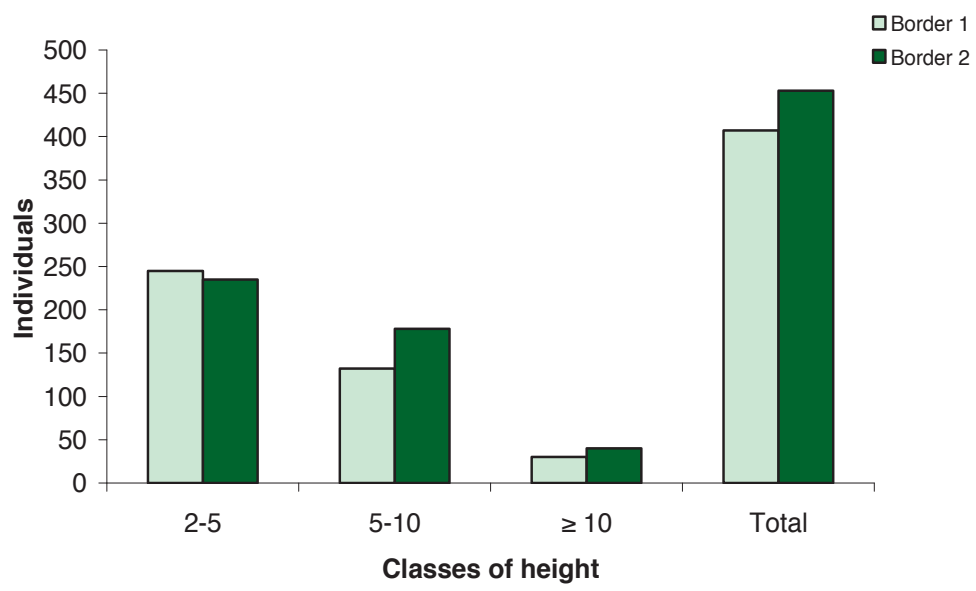

Figure 8. Vertical structure distributed in three classes of height (Borders 1 and 2 of the area that is rehabilitated) in the riverside of the Cuyaguateje.

Therefore, the biggest heights and diameters were represented by the smallest quantity in individuals. Such results coincide with reports by [32], who found low percentages of achievements and survivals in the plantations carried out by States Enterprise, as a consequence of the social insubordination of the residents, the inadequate selection of species and plantation methods during the reforestation, together with only partial participation of the local farmers in the reforestation plans. The biggest values of abundance found in the inferior stratum (a result of natural regeneration), indicate that the area has the potential to recover naturally. As [45] states, a high number of juvenile and young adults can be indicative of a stable or even an expansive population.

\subsubsection{Conservation degree of the rehabilitated area}

The conservation grade that is presented to an ecosystem is conditioned by the different indicators evaluated. Consideration of the behaviour of these indicators allowed for the inclusion of various elements in planning the complete forest rehabilitation. Identifying the causes of deterioration constitutes a fundamental link in their later management. Starting from the results obtained in the indicators evaluated according to [13], it was proven that the ecosystem is at the beginning of the rehabilitation stage: forest cover reached $72 \%$ of the surface, 
the modification degree was in the stocking category, the forest has recovered $26 \%$ of the original species, impacting on the recovery of the secondary forest. The summary of the evaluated aspects is shown in Table 14. If the different conservation categories suggested by [46] are used, and the sum of the values is assigned to each one of the evaluated parameters, the conservation degree of the vegetation cover was in the range of 10 , indicating that it was fairly conserved (Table 15).

\begin{tabular}{|c|c|c|}
\hline \multirow{2}{*}{ Indicators } & \multicolumn{2}{|c|}{ Riparian forest of "River Cuyaguateje" } \\
\hline & Index & Evaluation \\
\hline Original species grade & High - Media & 2 \\
\hline Stratification grade & Low Media & 1 \\
\hline Cover grade & Very high & 3 \\
\hline Modification grade & Media & 2 \\
\hline Synanthropic index & 0,19 & 1 \\
\hline Invader species grade & Media - low & 1 \\
\hline Total of accumulated points & & 10 \\
\hline
\end{tabular}

Table 14. Summary of indicators evaluated to determine the conservation degree of the riparian forest alongside in the River Cuyaguateje according to [13 and 46]

\begin{tabular}{ccc}
\hline Sum of total values & Rehabilitation grade & Category of conservation \\
\hline 10 & Beginning of rehabilitation & Fairly conserved \\
\hline
\end{tabular}

Table 15. Rehabilitation grade of riparian forest in its middle reaches.

The arguments mentioned previously present the result of the rehabilitation of the riversides of the Cuyaguateje, achieved through the participation of the executer actors (farmers and families). Study [5] shares similar approaches, indicating that rehabilitation does not imply that the site achieves an original, pre-disturbance ecological state. As the author explains, it is possible that a forest can recover its ecosystem function without recovering its structure completely. In many cases, the plantation of native trees or dominant pioneer species of ecological importance can help to start the rehabilitation process. Source [47] considers that ecological rehabilitation is an intermediate level between a degraded system and a restored ecosystem, with a composition and structure that can be similar or dissimilar to that of predisturbance. The restored system can be self-sustaining and used to provide ecological services, as in wooden production, medicinal products, and food, among others. 


\subsubsection{Participative strategy for the rehabilitation of the Cuyaguateje's riversides}

Local actors' perception about the riparian forest of the River Cuyaguateje is very important for successful biodiversity restoration. As outlined by [47]: "In Cuba the care and the conservation of the biodiversity has advanced, and the existence of legal, logistical and infrastructural means that guarantee the operation of a good part of the environmental system, but this is still not enough". Participative methods applied in the present research contributed towards positive positions about the economic, environmental, and social perception of the local actors that live and work adjacently to the riparian forest. This study promoted environmental education as a result of the training that was implemented in this area. Local residents also have a particular perception of the legislation for the protection of the riverside forest. Figure 9 shows that the biggest incidence of infractions made by the local actors in the riversides of the River Cuyaguateje was during the period 2001-2004. A gradual decrease was observed, starting from 2004, when the participative work took place. A change in local residents' perspective was probably a consequence of acquired knowledge and environmental consciousness.

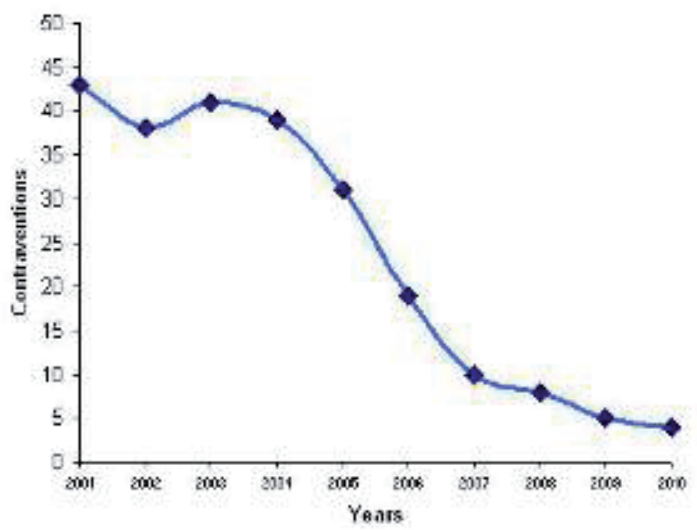

Figure 9. Trends of the infractions made by the local actors in the Cuyaguateje's riversides in the period 2001-2010.

Frequency analysis on the perception of local actors about regulations showed that $83 \%$ (24/29) of the interviewed actors could be classified as having the positions of advanced perception (Figure 10). It is very promising to realize that $78 \%(18 / 23)$ of the local residents are in advanced positions, or in other words, they know the regulations applicable in the riverside (minimum forest width, compulsory reforestation, and silvicultural management to be carried out, etc.). Local actors that only recognize the authority of the Forest State Service (FSS) and the fact that it has more than enough forest patrimony $22 \%(5 / 23)$ are classified as having intermediate positions. The lack of local residents classified in last group indicates a change in the perception and knowledge of legislation from the date of the initial surveys. This demonstrates the influence of the training actions and the high motivation showed by locals at the participative workshops and visits to the field. 


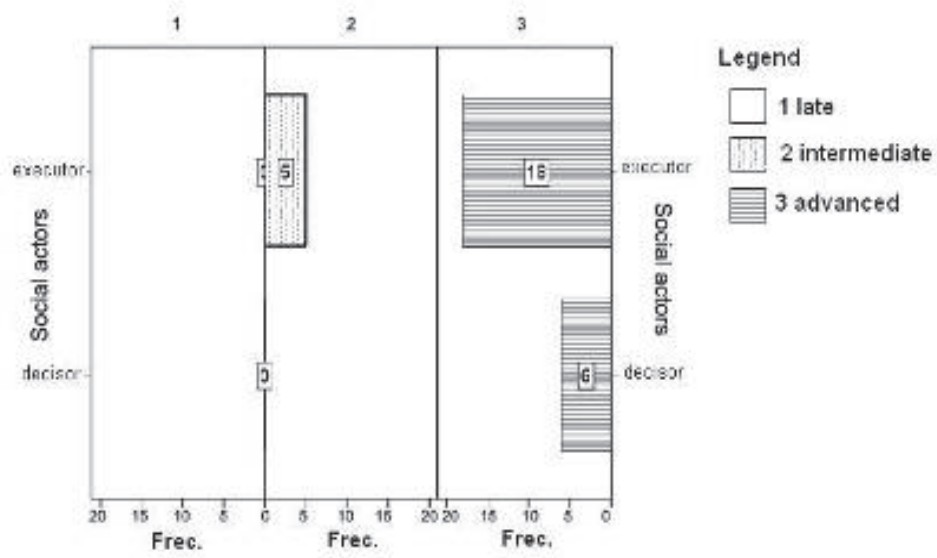

Figure 10. Distribution of frequencies obtained according to the perception of local actors on legislation governing the Cuyaguateje's riversides.

Our results contrasted with other studies without previous participative work from the local communities, such as the one carried out for [48] on the riversides of the River Caona. In that case, frequencies of high awareness positions were considerably low, about $30 \%(4 / 13)$. Therefore, it seems likely that the inclusion of a Participative Action Investigation (PAI) allowed the local actors to acquire knowledge on regulations for the protection of the riverside forests. Our results were also validated by the positions of the farmers and officials of the Forest State Service (FSS) during interviews and fieldwork. A good example is the change perceived in the farmer Noel Pérez. He became the informal leader of the community. A qualitative jump was perceived in his knowledge of the Forest Law, because he made several infractions until the year 2002, due to ignorance of the established regulations. After the training carried out in the participative workshops, the sense of ownership and commitment toward the riverside forest increased. This was evidenced in the results obtained in reforestation and establishment of the plantations, with the area belonging to Mr Pérez becoming the forest laboratory of the University Campus of Guane municipality and the Pinar del Río University.

Another example that confirms the necessity of introducing participative methods in the recovery of riparian forests is the study carried out by [49], in the basin of the River Sesesmiles (Honduras). These authors declared that $90 \%$ (18/20) of the local farmers did not know the legislation about the width of riverside fringes, although $75 \%(15 / 20)$ of the residents recognized the necessity of receiving training on the topic, and that is the state that watches over the execution of the established protection laws.

The approach in our research is that tree populations are the main agent to be managed when transforming the ecosystem. With an active participation of local residents it was possible to use their experience and to discuss with the scientists which tree species were more important for ecosystem rehabilitation. Most of the local residents showed a high degree of awareness 
(Figure 11). About 78\% (18/23) of the interviewed farmers showed knowledge on the species that should be planted: they recognized the species typical of the ecosystem, and they identified the characteristics of such species with regard to their function in the riverside forests. Participative workshops together with the application of PAI created learning environments that allowed forest scientists to explain the reality better, and at the same time to find solutions to the problems identified by the local actors. In other words, PAI was used as a mean of social mobilization. The importance of traditional, experience-based knowledge by farmers was demonstrated by the selection of species and management regimes. Preference was observed towards tree species and autochthonous shrubs that can establish and grow by passive reforestation. The knowledge of the present species in the ecosystem is necessary. According to [33], the presence of multiple species provides the security that ecosystem health will be maintained during disturbances or other environmental changes.

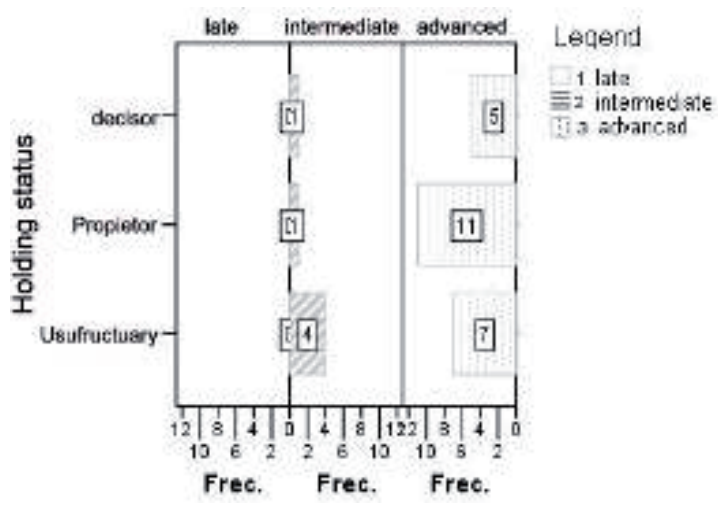

Figure 11. Distribution of frequencies of awareness of local residents on the appropriateness of forest species for riversides' restoration.

Local residents also showed knowledge on plantation times needed to obtain the best survival rates. Such times were related to previous results in riparian forests [10, 43-44, 50]. It is also important to recognize ownership status. Up to $92 \%(11 / 12)$ of the landowners behaved in terms of positions of advanced knowledge. They outlined as the main difficulties of achieving reforestation: the inadequate selection of species, the time for plantation, and especially the extensive impact of equine livestock. This livestock belongs to people that come from urban areas but who are not landowners.

Native farmers' knowledge of ecological communities and populations was of key importance. Their experiences contributed valid approaches about the species, reforestation methods, and the management of the restoration process. For example, the local Antonio Santoyo served as a guide to identify the species during the surveys of the riversides. He also indicated in workshops and interviews the most suitable species and the best methods for planting them.

Local empirical knowledge should be combined with the techniques of modern science to search for management regimes most suitable for the local ecological conditions. Farmers have 
accumulated knowledge that can be analysed by forest scientists, who in turn have scientific theories that can be put into practice. This is why it is important to implement participative methodologies. Social-participative ecosystem rehabilitation, with appropriate foundations, can be realizable and constitute an answer to some of the issues Cuba is facing at the moment. The decentralization of the environmental administration reinforces the grade of responsibility and the local residents' rights to forests. The knowledge that people have about their region, traditional uses of natural resources, location of the species, and in some cases the form of propagation of the plants, are important questions to consider in forest management plans. Indeed, to guarantee the success of reforestation it is important to combine academics' and farmers' knowledge on forest restoration practices. Unfortunately, this view has been usually dismissed in current research process not only for restoration but also in general silviculture.

Local residents were also aware of the socio-economic functions that riparian forests offer. Figure 12 shows that only $20 \%$ (6/29) of the local residents viewed the forest as useful only for timber. However, $72 \%$ (21/29) of local residents attributed to forests other functions of economic and social importance. This denotes that a transformation has been achieved as to the economic perception of the forest by locals. This result contrasted with those obtained by [48], where $77 \%$ of the interviewees assumed the forest to be exclusively a source of timber. In the same way, [49] diagnosed that only $45 \%$ of the farmers of the riverside of the River Sesesmiles (Honduras) perceived the riparian forests as having both economic and social value, because they offered products like fruits, firewood, and wood for the consumption of the family. According to [37], one of the goals of forest restoration could be the sustainable supply of goods and specific natural services for the social benefit of local residents.

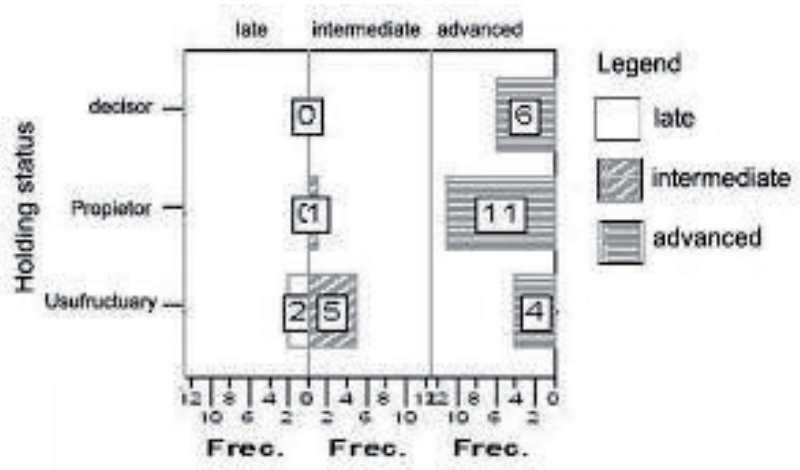

Figure 12. Distribution of frequencies obtained according to the perception of local actors about the socio-economic importance of riparian forest

As for the perception of the environmental function of the riparian forest, 52\% (12/23) of local residents interviewed had an environmental knowledge of the protection of the soil (an intermediate position). This understanding seems to be transmitted from ancestors, but it could be changed by the participatory research methods. Nowadays, $48 \%(11 / 23)$ of the farmers 
(owners and tenants) that are adjacent to the riversides of the River Cuyaguateje are in positions of advanced awareness, identifying the forest function on controlling soil erosion. They relate this ecosystem service to water quality and biological diversity. Local residents also recognize the impact that forests have beyond their boundaries (Figure 13).

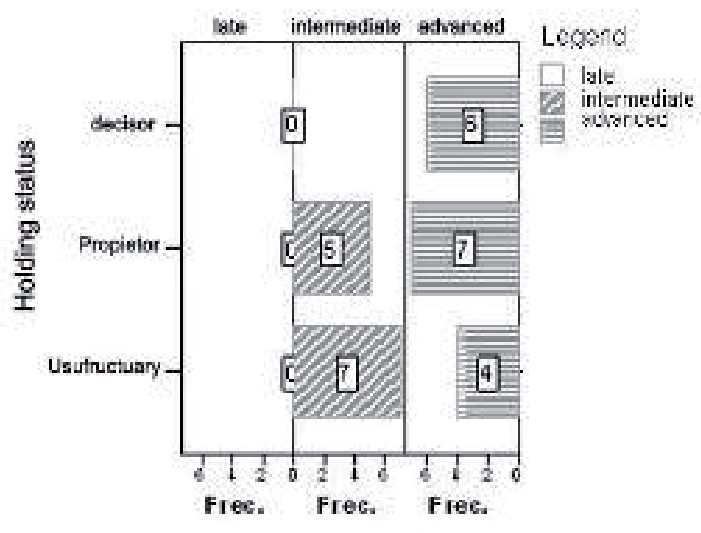

Figure 13. Distribution of frequencies obtained according to the perception of local actors about the environmental function of riparian forest.

In general, all the local actors recognized the forest's environmental functions. A group of them perceived the forest as an important element in the control of the current soil erosion in their farms. This aspect can be linked to the economic importance of forests, because farmers do not only see the forest as a source of timber, but rather they appreciate it as a tool for soil recovery that favours their crops and, therefore, their economy. No interviewed farmers were in late positions of awareness. The biggest proportion of advanced awareness was found for farmers that have lived all their lives in areas adjacent to the riverside, showing a sense of ownership toward this ecosystem. Therefore, the ownership status also influences the change of the perception in this variable. It highlights the polarization of the answers of the studied variable. Such a phenomenon especially affected the positions of advanced awareness, in which the interviewees identified the function of the forest in controlling the erosion of soil, and they related the forest with water quality and fauna migration. They also recognized the impact of the forest on the recovery of soil nutrients and food. As a consequence, there is an increment cultivation practices in bordering areas the forest. The testimonies aired in the workshops showed that farmers have appropriated the knowledge because they already attributed importance to the necessity of riverside protection. Therefore, they have not removed the soils of riverbanks; nor has the riverbed been altered by the formation of gullies in the areas lacking vegetation.

Local farmers were also asked "in their opinion, what are the causes of the present deterioration in the Cuyaguateje's riversides: direct or indirect human activity for long periods?" It was 
observed that all the local actors knew the causes of deterioration; these were identified as external and internal causes. In Figure 14, the positions of advanced knowledge are 69\% (20/29), with an important representation of those who have always lived in this community. The four tenants represented in the figure, are also from this location: they gave up their lands in a moment of their life and after Cuban's "special period" they got them back as tenants.

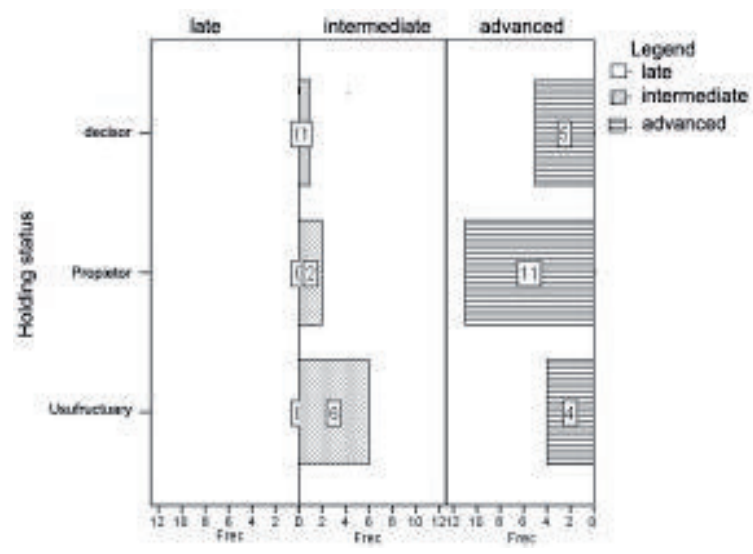

Figure 14. Distribution of frequencies obtained according to the perception of local actors on the deterioration causes of the Cuyaguateje's riversides.

As for the native farmers, cited deterioration causes were: dike construction, tree logging, sand extraction, and agricultural activities for tobacco production and other crops. Interestingly, they identified these causes as external, even the use of the soils for agricultural cultivation is for them a problem caused by their predecessors. Such a position shows low self-awareness of their impact on the environment, because they only identified responsibility in other actors different from themselves. Similar results were obtained by [48], who reported that $46 \%$ of the interviewees considered that the causes of forest deterioration are multiple, but never included the rural owners of these lands. Most of the farmers perceive the borders of the river as being their own property, or at least they think that they are entitled to use them and to manage them, in spite of the fact that the land is state property. Such aspect coincided with the results of [48-49].

Using available historical data and taking into account the riversides' situation in the year 2000 (the presence of scarce isolated trees), it can be assumed that the riversides were subjected to anthropogenic pressures, larger even than the natural causes mentioned above. Besides deforestation of the riversides, the riverbed has also been distorted, conditioned fundamentally by the expansion of agriculture, the lack of appropriate conservation techniques, and dike construction. In a general way, it is evident that the deterioration of native forests conditioned irreversible changes in the riverbed, both in the width of the river and in the formation of bends in the waterways [31-32]. 


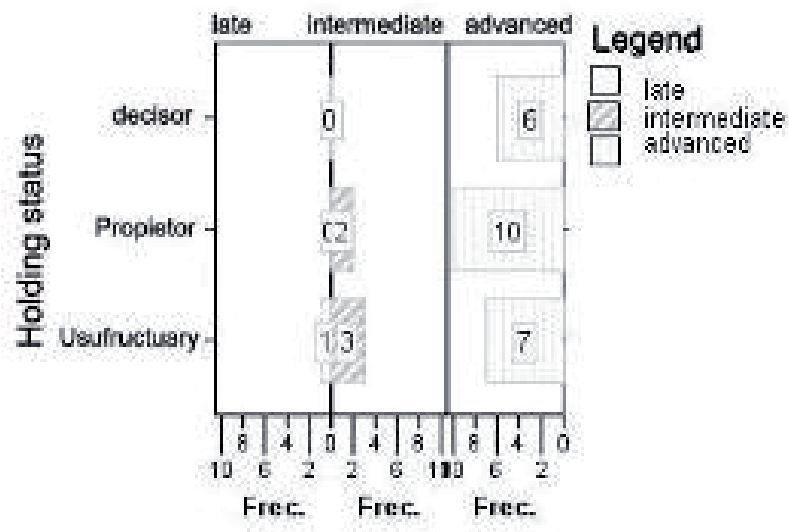

Figure 15. Distribution of frequencies obtained according to the perception of local actors on the most interested in reforestation in the Cuyaguateje's riversides.

Farmers that inhabit and work in the Cuyaguateje's riversides have always witnessed a deforested landscape. According to their recollections, the first reforestation actions began in the year 2000, with an audit procedure in which the Forest State Service, and businesses (Forest Enterprise Macurije, Tobacco Enterprise, and Enterprise of Several Cultivations) participated. It was coordinated by the Municipal Government's Direction. In that year, 22 hectares were planted for the first time. The biggest incidences of social indiscipline also happened. Starting from the year 2006, a gradual recovery of the riverside forest was observed, with the establishment of some trees that were planted and others that have colonized the site in a natural way as a consequence of the decrease of anthropogenic pressure (resulting from the knowledge acquired in the training workshops that began in the year 2004).

When local farmers were asked who is most interested in reforesting the riversides of the River Cuyaguateje, $96 \%$ of the interviewees (28/29) were considered in one way or another to have an interest in the reforestation, locating them in positions of intermediate and advanced awareness (Figure 15).

The behaviour of the local residents during the different participatory activities indicates a high disposition for auto-transformation. They proposed collective actions for their own community. They recognized the importance of their approaches in the rehabilitation process and that they can be part of decision-making about the tasks that impact the solutions of the outlined problems. In the same way, they recognized the necessity of collective action and participation: the systemic integration of everybody is necessary to implement actions. The previous position indicates the need to focus on the relationships among the local actors from a sociological perspective, where the cooperation of everybody prevails. Previous results on top-down approaches were not positive; it is necessary to integrate local residents' opinions and decide with them what is conceived for their environment. 
It is important in the rehabilitation process to focus on science, technology, and society. This requires that rehabilitation plans should have a range of political and strategies designed to incorporate feedback from local actors' experiences. To achieve the effective contribution of the executive managers, they have to be motivated and prepared by education. Therefore, one of the first actions to implement should be training stakeholders and decision-makers on the principles of sustainability. The decision-making actors should not adopt a technocratic and authoritarian position; they should frame their administration in the socio-cultural and natural context in which the problem is found. Coinciding with [48], we think this is one of the reasons why the traditional approaches to stop the problems associated with riverside management have, in most cases, failed. Therefore, to get sustainable forest administration of the riverside forests, the institutions, especially the Forest State Service, have to get adopt the paradigm 'Science, Technology, and Society'.

As for the local residents' perceptions about the actions of changes toward the reforestation, it was observed that $78 \%$ of the executive actors $(18 / 23)$ have carried out positive actions to the benefit of the riversides, including the decrease of cultivation and cattle ranching activities (Figure 16). A participative forest administration has become a primordial element in the strategies of forest administration: a structured collaboration between the government and the local actors (farmers) to manage forest resources in order to obtain common and sustainable objectives. Previous works have been executed, although not all of them have been favourable in outcomes. The failures have been mainly caused by the lack of participation of the local residents, such as the case of disproportionate plantation of exotic species (G. arborea and $A$. mangium) which have disordered the natural landscape. Such inadequate species selection produced low survival rates of G. arborea in the areas where floods last the longest. It is therefore necessary to increase the local knowledge and perception of riverside forests, since the points of view of the community actors are fundamental for achieving sustainable management. In this aspect, it is important to highlight the case of the rural community leader Noel Pérez for the good results obtained in that group's property. The Forest State Service has already certified four hectares of forest established on their property.

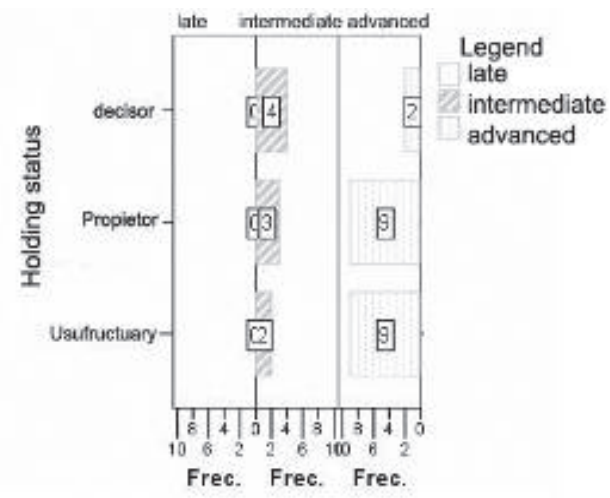

Figure 16. Distribution of frequencies obtained according to the perception of local actors on their tendency to the change in the Cuyaguateje's riversides. 
The final variable tested was the local perception of the most suitable method for reforestation. Figure 17 shows the results of perception analysis, with most of the actors leaning towards natural regeneration $(74 \%, 17 / 23)$. The main condition of achieving successful implementation is to eliminate the barriers that prevent natural regeneration. Regarding this issue, [51] outlined that when the stressing factors are eliminated in a degraded ecosystem, there is a trend that restoration follows. These authors asserted that success of the restoration does not only depend on the costs, funding sources, or the political will of the interested institutions. The main issue is the participation of the local communities with the power of decision over restoration plans.

As for the selected species, all the ones established during the regeneration or the plantations are valid. The improvement of a degraded system can also begin by means of the plantation of native trees, of dominant pioneer species and those of more ecological weight: all those that protect the riversides of the river. In this approach, local residents outlined the necessity of reforestation with native species, in addition to just leaving the land without agricultural management. Among the species that were identified as suitable for natural regeneration are: L. domingensis, G. ulmifolia, S. saman, T. catappa, T. hirta, S. saponaria, T. angustata, B. simaruba, C. collococca, T. citrifolia, R. regia, C. dentata, A. reticulata, C. hirsuta, A. inermis, and S. mombin. It was also identified G. sepium, to be regenerated through direct seeding or by planting stakes.

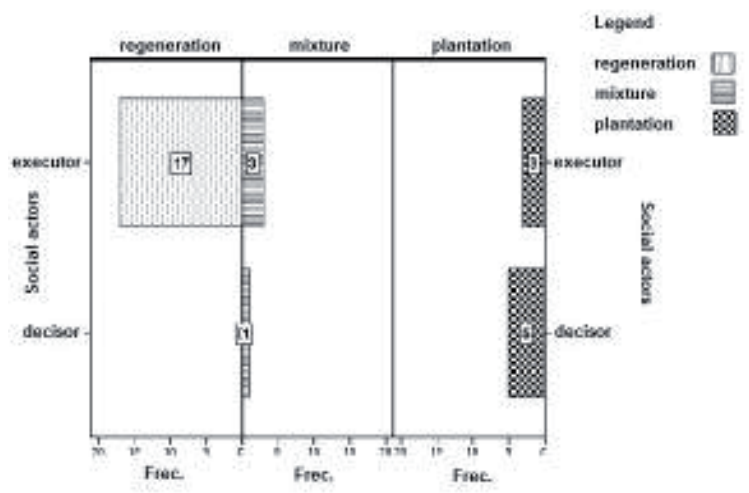

Figure 17. Distribution of frequencies obtained according to the perception of local actors on the most suitable reforestation method in the Cuyaguateje's riversides.

\subsubsection{Correlation between studied variables}

Table 16 presents the correlation analysis of the variables studied, applying the correlation coefficient Spearman's Rho. Significant relationships among several variables were found: local actors, perception of the environmental function, and the tendency to change. The 
variable "interest for the reforestation" was highly correlated with the perception of the environment, and less significantly with the perception of the suitable species. Correlation was also observed among the following variables: local actors, reforestation methods, ownership status, and origins of those interviewed.

\begin{tabular}{|c|c|c|c|c|c|c|c|c|c|c|c|}
\hline & $A L$ & ET & PE & PSLF & PSFA & PSEI & PSCD & PSIE & IR & TC & MR \\
\hline $\mathrm{AL}$ & 1,000 &,$- 754(* *)$ &,$- 637(* *)$ &,- 233 &,$- 429\left(^{*}\right)$ &,- 051 & ,127 &,- 312 &,- 260 &, $393\left({ }^{*}\right)$ &,$\left.- 6588^{(* *}\right)$ \\
\hline ET &,$- 754\left(^{* *}\right)$ & 1,000 & ,302 &, $393\left(^{*}\right)$ &, $454\left(^{*}\right)$ & 240 & 132 &, $601(* *)$ & ,346 &,- 340 &, $464\left(^{*}\right)$ \\
\hline PE &,$- 637\left(^{* *}\right)$ & ,302 & 1,000 & ,077 & 362 & ,125 &,- 313 &,- 100 & ,314 &,- 253 &, $408\left(^{*}\right)$ \\
\hline PSLF &,- 233 &, $393\left({ }^{*}\right)$ & ,077 & 1,000 & ,173 &,- 008 & ,019 & ,286 & 201 &,- 306 & , 167 \\
\hline PSFA &,$- 429\left(^{*}\right)$ &, $454\left(^{*}\right)$ & ,362 & ,173 & 1,000 & ,262 & ,209 & 150 &, $606\left(^{* *}\right)$ & 193 &, $428\left(^{*}\right)$ \\
\hline PSEI &,- 051 & 240 & ,125 &,- 008 & ,262 & 1,000 & ,302 & 267 &, $390\left(^{*}\right)$ &, $393\left({ }^{*}\right)$ &,- 087 \\
\hline PSCD & ,127 & 132 &,- 313 & ,019 & 209 & ,302 & 1,000 & 152 & ,145 & ,244 &,- 145 \\
\hline PSIE &,- 312 &, $601(* *)$ &,- 100 & ,286 & 150 & ,267 & 152 & 1,000 & ,343 &,- 057 & ,295 \\
\hline IR &,- 260 & ,346 & ,314 & 201 &, $606\left(^{* *}\right)$ &, $390\left(^{*}\right)$ & ,145 & ,343 & 1,000 & ,051 & 298 \\
\hline TC &, $393\left(^{*}\right)$ &,- 340 &,- 253 &,- 306 & 193 &, $393\left(^{*}\right)$ & ,244 &,- 057 & ,051 & 1,000 &,- 167 \\
\hline MR &,$- 658\left(^{* *}\right)$ &, $464\left(^{*}\right)$ & $408\left(^{*}\right)$ & 167 & $428\left(^{*}\right)$ &,- 087 &,- 145 & 295 & 298 &,- 167 & 1,000 \\
\hline
\end{tabular}

Legend

P S L. Perception about legislation

PSIE. Perception about economic importance

\begin{tabular}{lll}
\hline AL. Local actors & PSFA. Perception of environmental function & IR. Interest in the reforestation \\
\hline ET. Ownership status & PSEI. Perception of suitable species & TC. Tendency to change
\end{tabular}

PE. Origin of those interviewed PSCD. Perception of deterioration causes $\quad$ MR. Reforestation method

* The correlation is significant at the level 0.05 (bilateral).

** The correlation is significant at the level 0.01 (bilateral).

Table 16. Correlation analysis among the studied variables. Correlation coefficient Spearman's Rho.

In other words, the local actors that are interested in reforestation also attribute importance to protection of the environment and at the same time they are those that have the best knowledge on the most suitable species for reforestation. Obviously, there was a change of attitude in the local actors related with the assimilation of knowledge. This behaviour is achieved when there is an empowerment of local actors regarding the problem to be solved, and they are motivated to promote the commitment and the responsibility of each one of them towards the local forest. In such a sense, [47] stated: "among social actors, psychological and social elements mediate. This does not mean that a concern for the environmental questions necessarily implies pro- 
environment behaviour. To achieve this point, a committed participation of the involved actors is needed". Those individuals that manifest sensitivity towards the environment are the most interested in reforesting the area and at the same time they plead for the insertion of the participative silviculture for the rehabilitation. This indicates a change of attitude and sense of ownership toward the riverside.

\subsubsection{Participative strategy and work lines for the rehabilitation of the riparian forest of the River Cuyaguateje}

The information needed to elaborate the participative strategy was:

- Characterization of the structure and composition of the rehabilitated forest with the participation of local actors.

- The results of encounters, interviews, workshops, visits, participative observations, and consultation of the different local actors, decision-makers, and executives.

- Meetings with technicians and specialists at municipal, provincial, and national levels.

- The results of the work carried out during a ten-year period in a case study of rehabilitation and "Participative Action Investigation", which served as a basis for the feedback of the strategy.

The objective of the strategy was to rehabilitate the riparian forest of the River Cuyaguateje in their middle reaches through participative silviculture and the method Participative Action Investigation, strengthening the capacities of the local actors, guiding them towards sustainable forest management, and to be based on the perceptions of the local actors, institutions, and technologies. The specific objectives were:

- To achieve the success of the strategies, methodologies, and programmes proposed by the state for the recovery of the riparian forest of the River Cuyaguateje in its middle reaches.

- To improve the ecological state of the riversides and the River Cuyaguateje, reforesting it with the participation of the local actors, with preferably autochthonous fruit-bearing and wood species, although exotic ones can be used if their adaptation has been proved, whenever the established technical and juridical norms are followed.

- To encourage the integration of local actors in the rehabilitation of this fluvial ecosystem, and their use of politics and management with sustainability approaches.

- To contribute with information and experiences to improve the performances that are carried out in the rehabilitation of the riparian forest of the River Cuyaguateje and other rivers in the country.

To achieve this participative rehabilitation, several strategic lines were proposed:

1. Analysis and real organization of the context. This line is focused on two basic objectives: one to locate the area and the other to organize the context. Having broad information on the topic is needed, which should include theoretical foundations and existing regulations, 
as well as the practical experience on previous programmes and strategies related to the topic.

2. Training and education. Both are the roads to obtaining knowledge, abilities, and skills. Also, to propitiate the change of attitudes towards favourable values for the rehabilitation, sustainable management, administrative capacity, and local organization on the riverside forest. Several processes were carried out at the same time: encounters with farmers, families, decision-makers, and researchers. The experiences of the local actors were exposed in the gully rectification, selection of species, and plantation methods. In the same way, decision-makers presented to the farmers scientific results on species and methods used for the rehabilitation of the riverside forests.

3. The committed participation of local actors. To achieve this three key elements are needed: local actors admit to being part of the problem, are allowed to participate which helps the acquisition of knowledge, and to play a part in deciding what bears on values formation. It is therefore necessary to link the ecological rehabilitation with the biocultural rehabilitation, such that the historical, cultural, social, aesthetic, and moral dimensions of the involved actors are included.

4. Silvicultural management under the modality of community participation. Social or participative silviculture is achieved with the inclusion of executor actors in the rehabilitation process, from the farmer and the community managing the forest to actions by the state and the community. The individual forest management for the farmer's family benefit should be established.

5. Self-management by the farmers of the riparian forest. This leads to better planning of the natural resources, transforming each farmer into the administrator of his/her riverside tract. They also become the main decision-maker in the selection of species and suitable methods for the reforestation, as well as the different silvicultural practices after forest establishment.

6. Protection activities and surveillance. Regulations concerning the protection of the riparian forests are indispensable tasks to obtain better results. Good technical results cannot be applied to contexts if agreements and regulation mechanisms are not in place.

7. Participative evaluation. Evaluation constitutes a basic requirement to measure the advances or limitations of the execution of the carried-out activities. It is a necessary feedback mechanism to identify obstacles and to look for alternative solutions in a timely fashion. It also allows reaching the goals agreed by all the parts (executers and decision-makers). The main purpose is to stimulate those who intervene in the rehabilitation to stop and meditate on what has happened in the past, with the purpose of making better decisions in the future. When carrying out the evaluation, the actors find out what has worked well or not, and why. By means of this process, there is the greater chance people will take better corrective measures, given that the actors are those that discover and understand these measures. 


\begin{tabular}{lll}
\hline Conglomerates & Plots & Total \\
\hline Conglomerate 1 & $1 ; 8 ; 11 ; 2 ; 36 ; 3 ; 28 ; 15 ; 34 ; 13 ; 14 ; 16 ; 21 ; 35 ; 5 ; 19 ; 31 ; 29 ; 32$ & 19 \\
\hline Conglomerate 2 & $6 ; 7 ; 12 ; 10 ; 30$ & 5 \\
\hline Conglomerate 3 & $4 ; 18 ; 17 ; 27 ; 33 ; 9 ; 24 ; 26$ & 8 \\
\hline Conglomerate 4 & $20 ; 22 ; 23 ; 25$ & 4 \\
\hline
\end{tabular}

Table 17. Resulting conglomerates by means of Ward's linking method.

\subsection{Study of case No. 3: The native rainforests of the Toa's sector Quibiján-Naranjal}

\subsubsection{Diversity of species in native forests exploited in the basin of the River Toa (sector Quibiján- Naranjal)}

A total of 36 plots were sampled that represented the overall ecosystem. The cluster analysis based on Sorensen's similarity showed four clusters (Table 17).

The first conglomerate accounted for plots containing species of high economic and ecological value, such as B. buceras, C. antillanum, $H$. elatus, and Purdiaea velutina. These plots, although distant from each other, presented very similar flora. The second conglomerate was also notorious for the presence of species with high commercial value and ecological importance, such as: Castilla elastica, G. guara, Spondias mombin, Cedrela odorata, and Carapa guianensis. An important proportion of the present species in the study, are heliophytes species (which grow best under direct sunlight), many of them commercially important and reported in Neotropical forests such as C. antillanum, C. utile, and B. capitata. Conglomerates III and IV presented a mix of species (C. antillanum, C. peltata, H. elatus, C. odorata, C. guianensis, A. inermis, and J. vulgaris) that varied in abundance. The presence of pioneer species clearly indicates anthropic activities. These species had regenerated easily because the seeds are big and heavy, which favours germination. In general, the four groups share almost all the species, the rare species being Guazuma tomentosa, L. domingensis, and G. sepium.

\subsubsection{Structure of the native forests in the sector Quibiján-Naranjal of Toa}

Regarding the horizontal structure of the forest, Table 18 shows the 10 species with the highest abundance, frequency, dominance, and IVIE. The species with more IVIE were H. elatus, C. antillanum, S. laurifolium, G. guara, and T. catappa. This ecological importance value index represents the intricate relationships that the species maintain with other species of plants and organisms that help to maintain the dynamic and functional balance of the ecosystems [36].

\begin{tabular}{llcccc}
\hline No. & \multicolumn{1}{c}{ Species } & Abundance (\%) & Frequency (\%) & Dominance (\%) & IVIE (\%) \\
\hline 1 & Hibiscus elatus Sw. & 9,54 & 63,9 & 11,0 & 84,38 \\
\hline 2 & Calophyllum antillanum Britton & 8,11 & 61,10 & 2,81 & 72,04 \\
\hline 3 & Sapium laurifolium Griseb. & 5,19 & 61,10 & 1,26 & 64,78 \\
\hline
\end{tabular}




\begin{tabular}{llcccc}
\hline No. & Species & Abundance (\%) & Frequency (\%) & Dominance (\%) & IVIE (\%) \\
\hline 4 & Guarea guara (Jacq.) P. & 7,01 & 50,00 & 4,70 & 58,93 \\
\hline 5 & Terminalia catappa L. & 5,00 & 47,20 & 3,26 & 55,48 \\
\hline 6 & Syzygium jambos L. & 5,65 & 44,40 & 1,29 & 51,38 \\
\hline 7 & Cecropia peltata L. & 2,66 & 47,20 & 2,87 & 49,98 \\
\hline 8 & Spondias mombin L. & 3,11 & 4,44 & 3,29 & 48,07 \\
\hline 9 & Carapa guianensis Aubl. & 2,79 & 33,30 & 8,92 & 45,05 \\
\hline 10 & Zanthoxylum martinicense Lam. & 2,99 & 38,90 & 4,04 & 43,14 \\
\hline
\end{tabular}

Table 18. Abundance, Frequency, Dominance, and IVIE of the native forests of the sector Quibiján-Naranjal of Toa.

Table 19 shows how Jambosa vulgaris is one of the most abundant species, and it is also recognized in Cuba as invasive taxa [38]. This species is altering the structure and function of the forest. That fact is corroborated by [41-42], who stated that for this plant community valuable species are $C$. antillanum, $A$. inermis, and H. elatum, but generally in a smaller proportion. Owing to the anthropic pressure of the local communities, the species that are more plentiful are of scarce woody value; prevailing in higher proportions are Syzygium jambos and other species like C. peltata, G. guidonia, L. domingensis, and Bursera simaruba. Source [55] confirmed that these species present good adaptation to the soil and climatic conditions of the strip forest of the River Toa.

\begin{tabular}{lcccccc}
\hline \multirow{2}{*}{ Species } & \multicolumn{2}{c}{ Inferior Stratum } & Medium Stratum & Superior Stratum \\
\cline { 2 - 7 } & $\begin{array}{c}\text { Number of } \\
\text { trees }\end{array}$ & PS & $\begin{array}{c}\text { Number of } \\
\text { trees }\end{array}$ & PS & $\begin{array}{c}\text { Number of } \\
\text { trees }\end{array}$ & PS \\
\hline Syzygium jambos L. & 60 & 13,69 & 24 & 2,98 & 0 & 0 \\
\hline Guarea guara (Jacq.) P. & 34 & 7,76 & 58 & 7,21 & 3 & 3,44 \\
\hline Terminalia catappa L. & 32 & 7,30 & 41 & 5,09 & 0 & 0 \\
\hline Calophyllum antillanum Britton. & 28 & 6,39 & 91 & 11,31 & 1 & 1,14 \\
\hline Hibiscus elatus Sw. & 26 & 5,93 & 49 & 6,09 & 25 & 28,70 \\
\hline Dendropanax arboreus L. & 20 & 5,56 & 16 & 1,99 & 0 & 0 \\
\hline Sapium laurifolium Griseb & 24 & 5,47 & 47 & 5,84 & 8 & 9,19 \\
\hline Casasia calophylla A. Rich. & 5 & 1,14 & 5 & 0,62 & 0 & 0 \\
\hline Mangifera indica L. & 6 & 1,36 & 13 & 1,61 & 0 & 0 \\
\hline Acalypha diversifolia Jacq. & 7 & 1,59 & 18 & 2,23 & 1 & 1,14 \\
\hline Andira inermis (W. Wright) DC & 9 & 2,05 & 28 & 3,48 & 1 & 1,14 \\
\hline Zanthoxylum martinicense L. & 10 & 2,28 & 30 & 3,73 & 5 & 5,74 \\
\hline Ocotea leucoxylon Sw. & 12 & 2,73 & 3 & 0,37 & 0 & 0 \\
\hline Roystonea regia HBK & 17 & 3,88 & 32 & 3,98 & 0 & 0 \\
\hline
\end{tabular}

Table 19. Main species best represented in terms of sociological position in the native forests of the sector QuibijánNaranjal of Toa. 
Regarding the vertical structure of the forest, Table 19 shows that the main species with better sociological positions are Syzygium jambos in the lower canopy layer and C. antillanum in the intermediate canopy layer. In the superior canopy stratum, C. guianensis stands out together with H. elatus. These results indicate that in the forest there are not stable relationships in all the strata, nor is there evidence of the application of silvicultural systems. It seems that all canopy layers are affected by traditional management with a high intensity of indiscriminate tree felling, either for housing, firewood, or gap opening for agricultural cultivation. The superior stratum presents few species of economic importance [43]. Many of the existent species are not represented in all the strata. On the other hand, [53] outlines that a certain species takes an important role in the structure and composition of the forest when it is represented in all its strata. The author also said that the more regular the distribution of the individuals of a species in the vertical structure of a forest (gradual decrease of the number of trees as you ascend from the inferior stratum to the superior), so higher value in the phytosociological position.

\subsubsection{Influences of environmental variables in the structure of the native forest.}

The results of canonical correspondence analysis (CCA) were globally significant (trace $=1.876$, $\mathrm{F}=2.27$, and $\mathrm{P}=0.002$ ). The first four axes of the CCA offered a solution to the ordination of units of samplings and of species. Total variability in the data of species abundance (inertia = 3.609 ) explained $49.2 \%$ of the relationship between environmental variables and species distribution, and $26 \%$ of the variance of species distributions in each group. These results indicate a strong gradient (Table 20), because for ecological data the value of inertia is typically low (smaller than 10\%), especially when they present strong gradients [50]. The significance test of the first canonical axis demonstrated that this was also statistically significant, with auto-value $=0.316, \mathrm{~F}=2.15$, and $\mathrm{P}=0.0020$ (Figures 18 and 19).

\begin{tabular}{|c|c|c|c|c|c|}
\hline Number of canonical axis: 4 & Axis 1 & Axis 2 & Axis 3 & Axis 4 & Total Inertia \\
\hline Auto-values: & 0,316 & 0,250 & 0,198 & 0,173 & 3,609 \\
\hline Correlation species - environmental values: & 0,956 & 0,931 & 0,884 & 0,938 & \\
\hline
\end{tabular}

Accumulated percentage of the variance

\begin{tabular}{llccc}
\hline of data of species : & 8,8 & 15,7 & 21,2 & 26,0 \\
\hline of relation of species-environmental values: & 16,6 & 29,8 & 40,1 & 49,2 \\
\hline Sum of auto-values & & & 3,609 \\
\hline Sum of canonical auto-values & & & 1,902 \\
\hline
\end{tabular}

Table 20. Result of the canonical correspondence analysis (CCA) of species abundance, transformed logarithmically in each one of the 36 sampling units in the function of their environmental variables. 
The negative end of the axis 1 (CCA 1) shows a relationship with "distance to the highway (DCAR)" and with "distance to housing (DVIV)". Although in a smaller proportion, the negative end of the axis 2 (CCA 2) is also related to increases of the altitude (Alt), and slope (PEN). The positive end of axis 3 (CCA 3 ) is associated to match increase (P), distance to the highway (DCAR), and organic matter (MO), and in its negative end it is related to distance to the highway (Figure 19). Plots of group I correspond to slope gradient and altitude (Figure 18 and 19), while plots of group III are ordered following a gradient of distance to the highway and housing. The results of the ordination using the CCA 1 and CCA 3 show an evident distinction for the separation among plots of groups I, II, and IV for the variables' explanatory measures and for the separation of group III. While C. elastica, G. guara, C. odorata, T. catappa, and S. mombin species are present in plots of group III, they are associated with distance to the highway and distance to roads, coinciding with observations in the research area that research plots of group III have bigger anthropogenic activity that facilitates the development of secondary species.

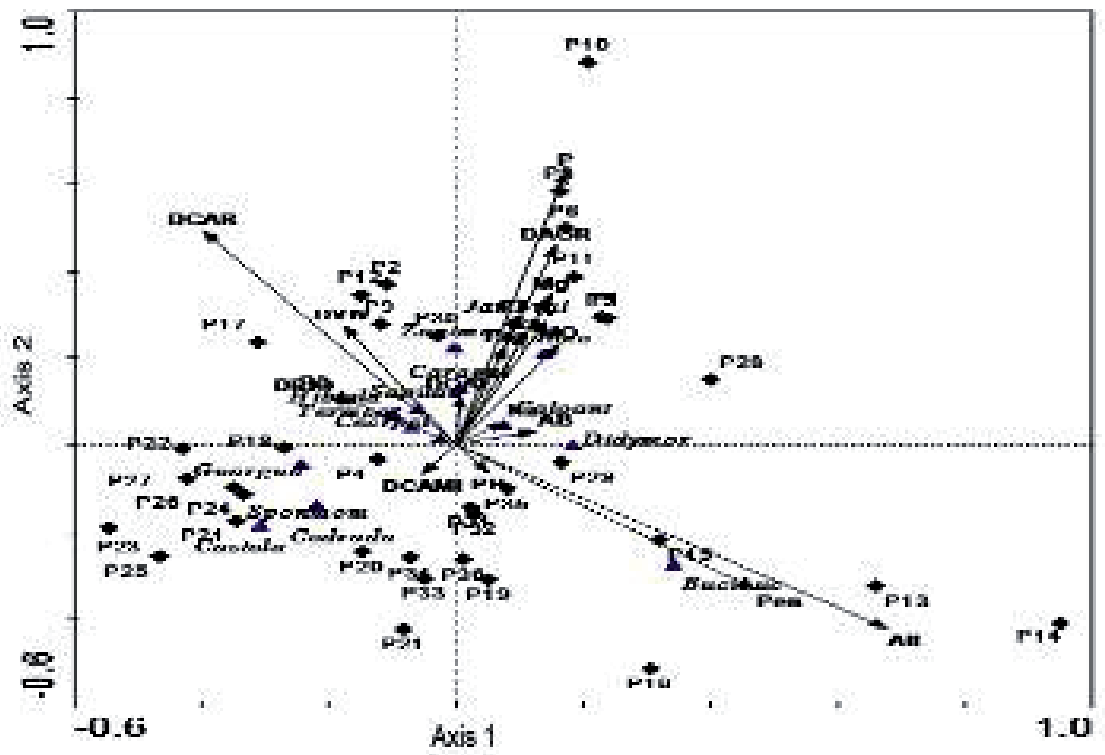

Figure 18. Projection of environmental variables, in census units and 15 species of bigger IVIE of the analysis of canonical correspondence in relation to the axes ACC1 and ACC2. The plots are the rhombuses, the species are the triangles, and the ecological variables are the arrows. Codes: Hibiela = Hibiscus elatus, Caloant = Calophyllum antillanum, Sapilau = Sapium laurifolium, Guargua $=$ Guarea guara, Cecrpel $=$ Cecropia peltata, Termcat $=$ Terminalia catappa, Jambvul $=$ Jambosa vulgaris, Sponmom $=$ Spondias mombin, Andiine $=$ Andira inermis, Zantmar $=$ Zanthoxylum martenicense, Caragui $=$ Carapa guianensis, Didymor $=$ Didymopanax morototonii, Cedrodo $=$ Cedrela odorata, Castela $=$ Castilla elastica, Buchecap $=$ Buchenavia capitata. 


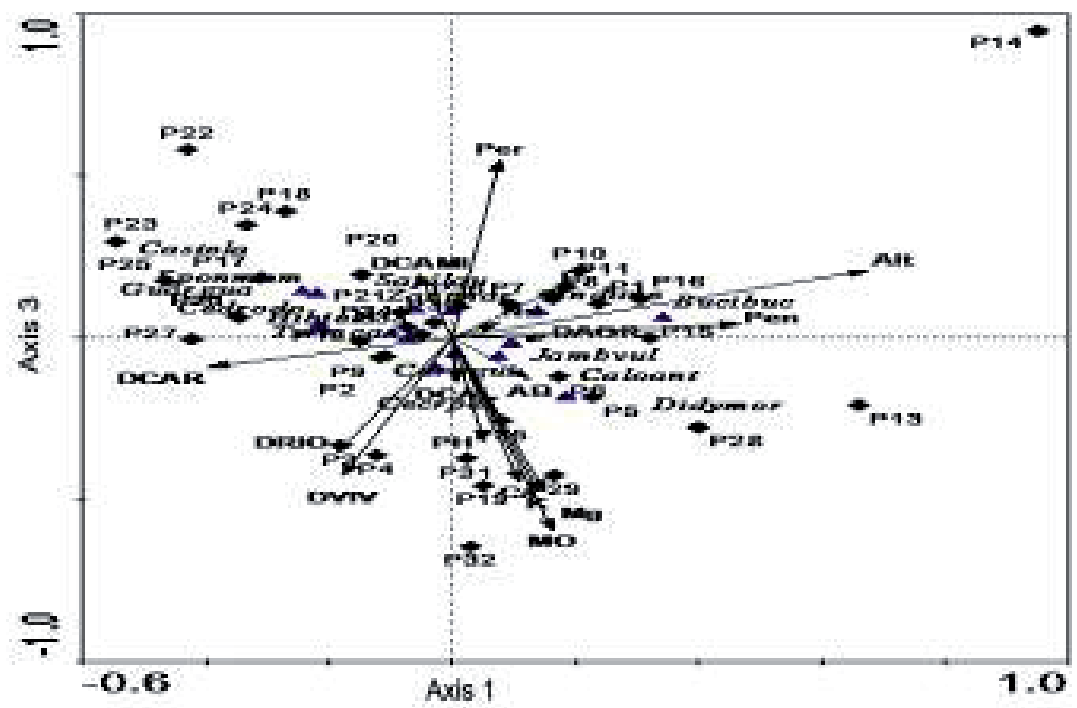

Figure 19. Projection of environmental variables, plots, and species of canonical correspondence analysis in relation to the axes ACC1 and ACC3. Codes: Hibiela = Hibiscus elatus, Caloant = Calophyllum antillanum, Sapilau = Sapium laurifoli um, Guargua = Guarea guara, Cecrpel $=$ Cecropia peltata, Termcat $=$ Terminalia catappa, Jambvul $=$ Jambosa vulgaris, Sponmom $=$ Spondias mombin, Andiine $=$ Andira inermis, Zantmar $=$ Zanthoxylum martinicense, Caragui $=$ Carapa guianensis, Didymor $=$ Didymopana $x$ morototonii, Cedrodo $=$ Cedrela odorata, Castela = Castilla elastica, Buchecap = Buchenavia capitata .

\subsubsection{Proposal for rehabilitation of native forests in the sector Quibiján-Naranjal of Toa}

To design the restoration proposal, we have considered the approach by [5], who suggested 13 steps for the restoration plan.

- Step 1: Definition of the reference ecosystem. Knowledge of the region and its land-use history has been kept in mind when planning research to be carried out in the area. These are reflected in [11, 50, and 55].

- Step 2: Evaluate the current state of the ecosystem or community. Evaluate the structure, composition of species, and their ecological function. The study identified 24 families, 49 genera, and 52 species of angiosperm plants, for a total of 1507 individuals. The families with higher abundance increased the biodiversity, but they did not contain most of the individuals. This fact evidenced changes in the structure and composition of the species in the study area, as a consequence of selective logging, timber and firewood extraction, gap opening for subsistence agriculture, and road opening. These were the main sources of disturbances in the secondary forest to the riverside of the River Toa. 
- Step 3: Definition of the scales at organization levels. Scales: Regional - Basin Toa, Local Quibiján-Naranjal of Toa, Levels of organization community (biological) - secondary forest.

- Step 4: Establishing the scales and hierarchies of disturbances. Scales: 1: selective logging; 2: extraction of firewood: 3: gap opening for subsistence agriculture, and 4: total roads impact. Consequences of such disturbances: 1) irregularities in the diameter structure of species of high commercial value, 2) abundance of species of low commercial value, and 3) dominance of exotic species.

- Step 5: Achieving local community participation. Ecological restoration is an activity with different spatial and temporal scales, in which the anthropogenic disturbances play an important part in any scale that is chosen [5]. The interest and the consciousness of the different actors that are involved in the management of natural resources in Basin Toa form a very important aspect in the coordination and execution of the projects and programmes, according to the strengths and possibilities that they present. Training to guide the individuals of these communities towards a more scientific-based knowledge, development, and strengthening their abilities should be one of the objectives proposed in the action plan.

- Step 6: Evaluating regeneration potential. As for the evaluation of the regeneration potential, one should keep in mind the location, readiness of the species in the forest, abundance, and successional stage, with the objective of selecting a group of pioneer, dominant, and codominant species with high economic values. Tree species that present better sociological positions are in Table 19.

- Step 7: Identifying barriers to restoration. Natural barriers: 1) dominance of species with little commercial value, 2) abundance of exotic species, and 3) irregularities of the diameter classes of the species of high commercial value. Social barriers: 1) selective logging, 2) firewood extraction, 3) gap opening for subsistence agriculture, and 4) total roads impact.

- Step 8: Selecting the appropriate species for forest restoration. This is a very important step for the success of the restoration plan. It is the fundamental axis in any reforestation project that seeks to be carried out in a certain area with the objective of re-establishing ecological values and of conservation of the ecosystem in general. The application of modern silvicultural techniques that seek to go beyond the traditional ones, such as: the spaced group technique or planted selection forest, reforestation with native species, passive reforestation (using natural regeneration), and using agroforestry systems (the method of Taungya). This will frame a new vision in the silvicultural development of the local Enterprise for the sake of increasing the technical personnel's skill and training level. Combined with the nucleation strategy described by [55-57] that also contributes to the recruitment of native species, it will increase the effectiveness of the restoration of tropical forests. With the objective of achieving the quick recovery of the forest, species recommended [5] are: H. elatus, C. antillanum, and B. capitata. These species present high percentages of natural regeneration in places that have been affected by the action of the winds, selective logging, and the effect of borders of roads or agricultural cultivations. It is recommended to use species of high economic value and those that present high values of relative abundance, relative frequency, 
relative dominance, and importance value index, such as H. elatus, C. antillanum, C. guianensis, D. cubensis, and T. dubia.

- Step 9: Propagating and handling of the species. The species selected present their own qualities for forestry. Therefore, it is important to have knowledge of their characteristics, how to spread them, and how they are to be managed. The success of the programmes and plantation projects depends on this knowledge.

- Step 10: Selecting sites. Selected sites were chosen as product of field research that could give us precise information regarding scale levels and their regime of disturbances, as well as the level of anthropization in the ecosystem.

- Step 11: Defining the strategy to overcome the barriers to the restoration. In this step it should be determined how to use the so-called modern silviculture techniques that go beyond traditional forestry, such as: the technique of spaced dense groups for plantation, reforestation with native species, passive reforestation (using natural regeneration), and the agroforestry systems (the method of Taungya).

- Step 12: Monitoring of the restoration process. Monitoring is fundamental to understanding the behaviour of the ecosystem over time, to predict and/or to prevent unwanted changes, and for evaluating if objectives are met or whether pertinent modifications should be made.

- Step 13: Consolidating the restoration process. The consolidation of a restoration project implies that most of the barriers to restoration have been identified and overcome, and that the ecosystem evolves according to the outlined objectives. The maintenance works and monitoring programmes should indicate that the process goes on in a satisfactory way and the ecosystem begins to show self-sustaining properties, such as the enrichment of species, wildlife recovery, and re-establishment of environmental services related with the quality of the water and the soil [55-57].

\section{Conclusions}

The three study cases introduced in this chapter shows how restoration of degraded tropical forests is possible, if management plans are implemented in a thorough way and they involve local residents and administrations at different levels. The assessment of forest ecosystems condition is complex, and changing it will have a multifactorial impact that depends not only on the forest's structure but also on ecosystem resilience and on-going human pressure. The natural and induced changes in the flora have an influence on the sequence of ecological succession. Therefore, to design a potential restoration strategy, planning must begin from the holistic assessment of the ecosystem functioning (composition and structure) and the participative action of local communities.

Based on our results we can conclude that: 1) the illegal selective logging and the exploitation of forest for wood and non-woody forest products are the main stresses placed on the Cuban forest ecosystems in the last hundred years. 2) The implementation of modern silviculture techniques that use key species identified during intensive forest assessment should be the 
starting point for restoration of tropical forests. 3) The participative techniques during the rehabilitation and restoration process should play a crucial role in the cases where the local communities govern the area to be restored. We think that such conclusions are applicable to most of the tropical forests around the world, without forgetting their own local particularities.

\section{Author details}

Eduardo González Izquierdo ${ }^{1^{*}}$, Juan A. Blanco², Gretel Geada López ${ }^{3}$, Rogelio Sotolongo Sospedra ${ }^{4}$, Martín González González ${ }^{5}$, Barbarita Mitjans Moreno ${ }^{6}$, Alfredo Jimenez González ${ }^{7}$ and José Sánchez Fonseca ${ }^{8}$

*Address all correspondence to: eduardo@upr.edu.cu

1 Forest Research Centre, Pinar del Río University, Pinar del Río, Cuba

2 Universidad Pública de Navarra, Pamplona, Spain

3 Biology Department, Pinar del Río University, Pinar del Río, Cuba

4 Forestry Department, Pinar del Río University, Pinar del Río, Cuba

5 Sociocultural Studies Department, Pinar del Río University, Pinar del Río, Cuba

6 Municipal University Centre of Guane, Pinar del Río University, Guane, Cuba

7 Agricultural Department, Artemisa University, Artemisa, Cuba

8 Agroforestry Department, Guantánamo University, Guantánamo, Cuba

\section{References}

[1] Blanco J. A. Aplicaciones de modelos ecológicos a la gestión de recursos naturales. OmniaScience. Monographs 2013. http://dx.doi.org/10.3926/oms.60

[2] Food and Agricultural Organization (FAO) Situación de los bosques del mundo 2007.

[3] Barrera I. and Valdés C. Herramientas para abordar la Restauración Ecológica de áreas disturbadas en Colombia. Revista de la Facultad de Ciencias Edición especial II, 2007; 12:11-24.

[4] Gann G. D. and Lamb D. La restauración ecológica - un medio para conservar la biodiversidad y mantener los medios de vida. http//:www.ser.org (Accessed June 2012) 2009. 
[5] Vargas O. Los pasos fundamentales en la restauración ecológica. Universidad Nacional de Colombia. Guía Metodológica para la Restauración Ecológica del Bosque Altoandino. Grupo de Restauración Ecológica, Universidad Nacional de Colombia, 2008

[6] Hernández F. Restauración de la diversidad vegetal arbórea de los bosques siempreverdes de la Reserva de la Biosfera Sierra del Rosario (RBSR), Pinar del Río, Cuba. PhD thesis. Universidad de Pinar del Río, Cuba and Universidad de Alicante España. 2010.

[7] Herrera R., Menéndez L., Rodríguez M. E., and García E. E. (Eds.) Ecología de los Bosques Siempreverdes de la Sierra del Rosario, Cuba Proyecto MAB No. 1, 19741987. Instituto de Ecología y Sistemática. Academia de Ciencias de Cuba. 1988.

[8] ECOVIDA Plan de Manejo Reserva de la Biosfera Sierra del Rosario. Centro de Investigaciones y Servicios Ambientales ECOVIDA. Ministerio de Ciencias, Tecnología y Medio Ambiente, Pinar del Río Período 2011-2015. 2011.

[9] Berazaín R.; Areces F.; Lazcano J. C. and González L. R. Lista roja de la Flora Vascular Cubana. Documentos del Jardín Botánico Atlántico (Gijón) 2005; 4:1-86.

[10] Capote R. and Berazaín R. Clasificación de las formaciones vegetales de Cuba. Revista Jard. Bot. Nac. 1984; 5 (2): 26-37.

[11] Reyes O. J. and Acosta F. C. Vegetación en Cuba: Parque Nacional: Alejandro de Humboldt: Rapid Biological Inventories. 2005; (14): 54-69.

[12] Jimenez A. Contribución a la ecología del bosque semideciduo mesófilo en el sector oeste de la Reserva de la Biosfera "Sierra del Rosario", orientada a su conservación. PhD thesis. Universidad de Pinar del Río, Cuba; 2012.

[13] Mitjans, B. Rehabilitación del bosque de ribera del río Cuyaguateje, en su curso medio. Estrategia participativa para su implementación. PhD thesis. Universidad de Pinar del Río, Cuba; 2012.

[14] Sánchez J., González E., and Ferro J. Estructura de los bosques nativos explotados en la cuenca hidrográfica del Toa y su relación con variables ambientales. In: Proceedings of the VIII International Symposium on Sustainable Forest Management, Pinar del Río, Cuba. 2014.

[15] Pickett A. and White S. The Ecology of Natural Disturbance and Patch Dynamics. Academic Press, EE.UU. 1985.

[16] Finegan B and Bouroncle B. Patrones de fragmentación de los bosques de tierras bajas, su impacto en las comunidades y especies vegetales y propuestas para su mitigación. In: Harvey, C. (Eds.). Evaluación y conservación de biodiversidad en paisajes fragmentados de Mesoamérica. Santo Domingo de Heredia, Costa Rica, 2008. 
[17] Berry P. Diversidad y endemismo en los bosques neotropicales de Bajura, In: Guariguata, M.; Kattan, G. (Eds.). Ecología y Conservación de bosques neotropicales. 2002.

[18] Gentry H. Changes in Plant Community Diversity and Floristic composition on Environmental and Geographical Gradients. Ann. Missouri Bot. Gard. 1988; 75(1): 2-34.

[19] Keels S.; Gentry A. and Spinzi L. Using vegetation analysis to facilitate the selection of conservation sites in eastern Paraguay. (Biodiversity Measuring and Monitoring Certification Training, Volume 2). Washington: SI/MAB. 1997.

[20] Dufrene M. and Legendre P. Species assemblages and indicator species: the need for a flexible asymmetrical approach. Ecological Monographs 1997; 67:345-366.

[21] Feinsinger P. El diseño de estudios de campo para la conservación de la biodiversidad. Editorial FAN. Santa Cruz de la Sierra, Bolivia. 2003.

[22] Curtis J. T. and Mcintosh R. P. The interrelation of certain analytic and synthetic phytosociological characters. Ecology 1950; 31: 434-445.

[23] Connell H. Diversity in tropical rain forest and coral reefs. Biotropica 1978; 12: 47-55.

[24] Menéndez L., Capote P., and González V. La Reserva de la Biosfera. Áreas de Estudio. Capítulo 2. Ecología de los Bosques Siempreverdes de la Sierra del Rosario. Instituto de Ecología y Sistemática, Academia de Ciencias de Cuba. Proyecto MAB No. 1, 1988 .

[25] Davic D. Linking keystone species and functional groups: a new operational definition of the keystone species concept. Cons. Ecol. 2003; 7:11.

[26] Cofiño C. E. Características microestucturales de las secuencias del Jurásico SuperiorCretácico y su relación con la potencialidad de Hidrocarburos en la parte Oriental de Sierra del Rosario. PhD thesis. Universidad de Pinar del Río, Cuba. 2002.

[27] García M. Conservación y Manejo in situ de la Biodiversidad en Huertos Caseros y Fincas de Cuba. PhD thesis. Universidad de Pinar del Río, Cuba and Universidad de Alicante España. 2006.

[28] Garibaldi C. Efectos de la extracción y uso tradicional de la tierra sobre la estructura y dinámica de bosques fragmentados en la Península de Azuero, Panamá. PhD thesis. Universidad de Pinar del Río, Cuba; 2008.

[29] OIMT (Organización Internacional de Maderas Tropicales). Directrices de la OIMT para la restauración, ordenación y rehabilitación de bosques tropicales secundarios y degradados, Serie de políticas forestales No. 13. 2002.

[30] Gerhartz J. L., Estrada R., Hernández E., Hernández A., and González A. Metodología para la elaboración de los planes de manejo de las áreas protegidas de Cuba. Centro Nacional de Áreas Protegidas de Cuba (CNAP), Editorial Feijóo, 2007.

[31] Mitjans B., Lago A., Beato S., González E., and Sánchez J. Estudio del comportamiento de la Acacia mangium en la faja hidrorreguladora del río Cuyaguateje. In: Proceed- 
ings of the V International Symposium on Sustainable Forest Management, Pinar del Río, Cuba. 2008.

[32] Mitjans B., Bonilla M., Suárez A. G., González E., and González M. Estado de conservación del bosque de ribera del río Cuyaguateje (Municipio Guane). In: Proceedings of III International Symposium of Ecological Restoration, Santa Clara, Cuba. 2010.

[33] Barrera J.; Contreras N.; Rodríguez V.; Moreno A. and Montoya S. Manual para la Restauración Ecológica de los Ecosistemas Disturbados del Distrito Capital. Secretaría Distrital de Ambiente (SDA), Pontificia Universidad Javeriana (PUJ). Bogotá, 2010 .

[34] Magurran A. E. Ecological diversity and its measurement. Princeton University Press, New Jersey, 1988.

[35] Moreno C. E. Métodos para medir la biodiversidad. M\&T - Manuales Tesis SEA, Vol.1. Zaragoza. 2001.

[36] Vales M., Vilamajó D., and Herrera P. Especies forestales e integridad ecológica en fragmentos de bosques semideciduos de la provincia de La Habana, Cuba. In: Proceedings of the V Forestry Congress of Cuba. 2011.

[37] SER Principios de SER Internacional sobre la restauración ecológica. Society for Ecological Restoration (SER) Internacional. Grupo de trabajo sobre ciencia y políticas. www.ser.org y Tucson: Society for Ecological Restoration International. 2004.

[38] González L. R., Rankin R., and Palmarola A. (Eds.) Plantas invasoras en Cuba. Bissea 2012; 6(1):22-96.

[39] Servicio Estatal Forestal (SEF) Informe Balance anual de la dinámica forestal y la reforestación de las riberas del río Cuyaguateje. 2005.

[40] Jaramillo H. Guía para estudiar estructura de Bosque Natural UTLVT/FACAAM/ Escuela de Ciencias Forestales y Ambientales. http//:www.scrib.com/doc/27722564. (Accessed September 2010) 2009.

[41] Lamprecht H. Silvicultura en los trópicos. Los ecosistemas forestales en los bosques tropicales y sus especies arbóreas. Posibilidades y métodos para un aprovechamiento sostenido. Deutsche Gesellschaft für Technische Zusammenarbeit (GTZ) Gmobh. Alemania. 1990.

[42] Samek V. Regiones Fitogeográficas de Cuba. Dpto. de Ecología Forestal. Academia de Ciencias de Cuba. Serie Forestal 1973, (15).

[43] Álvarez P. A. and Varona J. C. Silvicultura, 2da reimpresión. Editorial Félix Varela, La Habana, 2007.

[44] Mitjans B., Bonilla M., Suárez A. G., González E., and González M. Propuesta participativa para la rehabilitación del bosque de ribera del Río Cuyaguateje. In: Proceedings of the V Forestry Congress of Cuba. 2011. 
[45] Primack R., Roíz R., Feinsinger P., Dirzo R., and Massardo F. Fundamentos de Conservación Biológica. Perspectivas latinoamericanas. Fondo de Cultura Económica. México, 2001.

[46] Matos J. and Ballate D. ABC de la restauración ecológica. Editorial Feijoó. Cuba. 2006.

[47] Núñez L. Las percepciones ambientales de actores locales en áreas protegidas cubanas. Ventajas y desventajas para asumir la sostenibilidad. http://dlc.dlib.indiana.edu/ archive/00001456/00/NúñezMorenoPercepciones_040512_Paper 583.pdf, (Accessed December 2010). 2004.

[48] Eupierre H. Adecuación de la metodología FFH al contexto sociocultural del sector campesino. El caso del río Caonao. MSc. thesis. Universidad de Pinar del Río. 2008.

[49] Arcos I., Jiménez F., and León A. Percepción local acerca del papel de los bosques ribereños en la conservación de los recursos naturales en la microcuenca del río Sesesmiles, Copán, Honduras. In: Recursos Naturales y Ambiente, CATIE. Costa Rica. 2006; (48): 118-122.

[50] Sánchez J. Criterios e indicadores en la faja hidrorreguladora del río Cauto. In: Proceedings of the VI Forestry Congress of Cuba. 2011.

[51] Vargas O. and Mora F. La restauración ecológica, su contexto, definiciones y dimensiones. In: O. Vargas (Ed). Estrategias para la restauración ecológica del bosque Alto andino. Universidad Nacional de Colombia. 2007.

[52] Corbin J. D. and Holl K. D. Applied nucleation as a forest restoration strategy. Forest Ecology and Management 2012; (265): 37-46. Doi: 10.1016/f.foreco 2011.10.013.

[53] Pouyú E. Synanthropic Liliatea and some other minor groups. Fontqueria 1995; 42:367-429.

[54] Ter Braak C. J. and Verdonshot F.M. Canonical correspondence analysis and related multivariate methods. Aquatic Ecology. Ecology Sciences 1995; 57: 255-286.

[55] Rodríguez Y. and Sánchez J. Diseño sostenible para la recuperación y conservación de las Fajas Forestales Hidrorreguladoras del río Toa. Guantánamo. In: Proceedings of DEFOR, La Habana, Cuba, 2005.

[56] Holl K. D., Zahawi R. A., Cole R. J., Ostertag R., and Cordell S. Planting seedlings in tree islands versus plantations as a large-scale tropical forest restoration strategy. Restoration Ecology 2011; (19): 470-479.

[57] Zahawi R. A., Holl K. D., Cole R. J., and Reid L. Testing applied nucleation as a strategy to facilitate tropical forest recovery. Journal of Applied Ecology 2013; (50): 88-96, doi 10.1111/1365-2664.12014. 
